\title{
Debt Enforcement, Investment, and Risk Taking Across Countries
}

\author{
Giovanni Favara ${ }^{\mathrm{a}}$, Erwan Morellec ${ }^{\mathrm{b},}$, Enrique Schroth $^{\mathrm{c}}$, and Philip Valta ${ }^{\mathrm{d}}$ \\ ${ }^{a}$ Division of Monetary Affairs, Board of Governors of the Federal Reserve System, \\ Washington DC, 20551, USA. \\ b Swiss Finance Institute, Quartier UNIL-Dorigny, Extranef 210, 1015 Lausanne, \\ Switzerland, EPFL, and CEPR. \\ ${ }^{\mathrm{c}}$ Finance Faculty, Cass Business School, City University London, 106 Bunhill Row, EC1Y \\ 8TZ, UK. \\ ${ }^{\mathrm{d}}$ University of Bern, Engehaldenstrasse 4, 3012 Bern, Switzerland, University of Geneva, \\ and Swiss Finance Institute.
}

August 5, 2016

\begin{abstract}
We argue that the prospect of an imperfect enforcement of debt contracts in default reduces shareholder-debtholder conflicts and induces leveraged firms to invest more and take on less risk as they approach financial distress. To test these predictions, we use a large panel of firms in 41 countries with heterogeneous debt enforcement characteristics. Consistent with our model, we find that the relation between debt enforcement and firms' investment and risk depends on the firm-specific probability of default. A differencesin-differences analysis of firms' investment and risk taking in response to bankruptcy reforms that make debt more renegotiable confirms the cross-country evidence.
\end{abstract}

Keywords: Debt enforcement; Default; Investment; Asset sales; Risk-taking.

JEL Classification Numbers: G31; G32; G33.

\footnotetext{
${ }^{*}$ Corresponding author. Tel.: +41 (0)21 693 0116; fax: +41 (0)21 6930110.

E-mail address: erwan.morellec@epfl.ch
} 


\section{Introduction}

A central result in corporate finance is that, as firms approach financial distress, key corporate decisions such as investment and risk taking get distorted by conflicts of interests between shareholders and creditors. Notably, the expectation of a low shareholder recovery in distress may lead shareholders in financially distressed firms to reject positive net present value (NPV) projects or to sell assets in place - the underinvestment effect of Myers (1977) - and to take on too much risk - the risk-shifting effect of Jensen and Meckling (1976).

The goal of this paper is to examine whether the enforcement of debt contracts in default affects the underinvestment and risk-shifting distortions caused by risky debt and shareholderdebtholder conflicts. To obtain empirical predictions relating debt enforcement to investment and risk choices, we develop a simple model of endogenous investment, asset sales, and risk taking in which debt enforcement affects the payoff to shareholders in default and, hence, corporate decisions close to default. The model synthesizes the theories of underinvestment (Myers, 1977), risk-shifting (Jensen and Meckling, 1976), and debt enforcement in default (Fan and Sundaresan, 2000). In the model, a firm operates risky assets and has risky, long-term debt outstanding. Management maximizes shareholder value and can make three decisions. First, it can invest in new assets. Second, it can reduce the scale of the firm by selling part of its assets before debt maturity. Third, it can change the risk of assets in place.

Using this model, we show that bankruptcy codes that favor debt enforcement decrease shareholders' expected recovery in default and, hence, the benefits of investment to shareholders. This mechanism implies that the distortions in investment and asset sales due to risky debt increase with debt enforcement in default and leads to the prediction that the effects of the default probability on investment decisions should be higher in countries with stricter debt enforcement. Additionally, we show that the prospect of a strict enforcement of debt contracts in default increases the convexity of shareholders' claim by decreasing their expected payoff in default. This leads to the prediction that the sensitivity of risk taking to the probability of default increases in countries with stricter debt enforcement.

We test these predictions using a panel of 18,602 firms in 41 countries with heterogeneous bankruptcy procedures, exploiting the cross-country variation in debt enforcement documented in the survey by Djankov, Hart, McLiesh, and Shleifer (DHMS, 2008). This survey 
shows that bankruptcy procedures vary substantially across countries and that an important source of heterogeneity is the amount of provisions for debt enforcement in default. In our empirical analysis, we construct a debt enforcement index with information from the DHMS survey and use this index to measure international variation in debt enforcement and shareholders' expected recovery in default. Because distortions in corporate policies are more likely when firms approach financial distress, our tests relate investment and risk to the interaction between the index of debt enforcement and firm-specific measures of default risk.

Our empirical analysis delivers three main results. First, distressed firms in countries with strict debt enforcement invest less than equally distressed firms in countries with weaker debt enforcement procedures. Notably, firms with a default probability higher than the third quartile breakpoint in countries where debt contracts are most likely to be enforced (where the Debt enforcement index has the maximum value of one) have an investment-to-assets ratio that is about $14 \%$ lower than similar firms in countries where debt contracts are least likely to be enforced (where the Debt enforcement index equals zero). Second, distressed firms' assets grow significantly less in countries where debt contracts are strictly enforced. On average, their asset growth rate is $79 \%$ smaller than that of distressed firms in a country with the weakest debt enforcement. Finally, distressed firms in countries where debt enforcement is strict are about $37 \%$ riskier, measured by total equity volatility, than similar firms in countries where debt enforcement is weaker.

The main challenge of our empirical analysis is that firms are not randomly assigned to different bankruptcy procedures. The utmost concern is that a country's bankruptcy procedure may be correlated with observable and unobservable country characteristics that are likely to affect firms' ability to invest or undertake risk through channels other than the enforceability of debt contracts. Our empirical framework attempts to control for such confounding effects by including time-varying firm and country characteristics, as well as country or firm fixed effects. The inclusion of country or firm fixed effects mitigates the concern that other unobserved country-specific factors may correlate with creditors' ability to enforce debt contracts. In addition, since firms close to distress are those that are most likely to be influenced by the bankruptcy procedures, our tests are conducted by exploiting firms' heterogeneity in their probability of facing financial distress. 
To strengthen the interpretation of the results, we also implement a differences-in-differences analysis around two sets of bankruptcy reforms that targeted the renegotiability of debt and, therefore, debt enforcement. The goal of this analysis is to validate our cross-country results in a setting that, by design, reduces the concern that our results may be driven by potential effects of unobserved country characteristics. In a first step, we explore the effects of three major bankruptcy reforms in France, Italy, and Brazil in 2005 that made debtor-initiated renegotiations easier (see Weber, 2005; Rodano, Serrano-Velarde, and Tarantino, 2016; Alencar and Ponticelli, 2016). In a second step, we focus on the 1978 U.S. Bankruptcy Reform Act, which had a major impact on distressed reorganizations under Chapter 11. This reform was designed to encourage debt renegotiation, by shifting bargaining power in reorganizations towards shareholders (see Hackbarth, Haselmann, and Schoenherr, 2015). In all cases, we compare investment, asset growth, and risk of firms with a high default probability around each bankruptcy reform to firms with a low default probability. Consistent with the crosscountry evidence, we find that high default probability firms invest relatively more and take on relatively less risk after the implementation of a reform than low default probability firms.

Our paper contributes to the literature on the real effects of debt enforcement. A recent strand of this literature shows that bankruptcy codes with fewer renegotiation frictions lead to larger debt reductions and reduce equity risk (see Fan and Sundaresan, 2000; François and Morellec, 2004; or Davydenko and Strebulaev, 2007). Consistent with this view, deviations from absolute priority caused by debtor-friendly bankruptcy codes have been shown to have important effects on equity returns both in the U.S. (see Garlappi, Shu, and Yan, 2008; Garlappi and Yan, 2011; and Hackbarth, Haselmann, and Schoenherr, 2015) and outside the U.S. (see Favara, Schroth, and Valta, 2012). While these studies assume that asset risk is given and independent of claimholders' expected recovery in default, we show that the prospect of an imperfect enforcement of debt contracts in default reduces asset risk. Therefore, our analysis suggests that the equity risk effects found in prior studies may not only be due to a leverage (i.e., capital structure) effect but also due to a risk-shifting effect.

Our paper also relates to the literature on agency conflicts and risk-shifting [see, for example, the recent empirical studies by Eisdorfer (2008), Gormley and Matsa (2011), Landier, Sraer, and Thesmar (2015)]. While risk-shifting incentives increase with the probability of dis- 
tress, this literature has so far ignored the effects of bankruptcy law on risk taking. The paper closest to ours in this literature is Becker and Stromberg (2012). Becker and Stromberg show that a strengthening of managerial fiduciary duties to creditors mitigates underinvestment and risk-shifting incentives for firms near insolvency. Our study shows that underinvestment and risk-shifting distortions are also mitigated if debt enforcement is imperfect and shareholders expect a higher recovery on the assets in default. Because weaker debt enforcement in default in fact may increase the payoffs to both shareholders and creditors by reducing default costs [as shown, for example, in Fan and Sundaresan (2000)], the findings in these two studies suggest that legal institutions can improve overall welfare near default by aligning shareholders' incentives with creditors' interests.

A parallel literature studies the role of private arrangements to mitigate reorganization or liquidation biases of bankruptcy laws. For example, Gennaioli and Rossi (2013) argue that, when creditor protection is high, efficient resolutions of financial distress can be achieved by writing private contracts that allocate control rights to shareholders and creditors over reorganization and liquidation decisions. Our results suggest that even if such private arrangements exist, they cannot offset completely bankruptcy codes' distortions, which is consistent with the evidence in Lerner and Schoar (2005) that contractual provisions provide only a partial solution to legal enforcement problems. Even so, our analysis does not rely on the assumption that debtors and creditors cannot write state-contingent contracts. It only requires that some contracting frictions prevent parties to write contracts that Pareto improve their welfare, for example, because such contracts cannot be perfectly enforced in court.

Our paper also contributes to the large empirical literature that studies the impact of creditor rights on firms' debt capacity and investment. While there is widespread evidence that a strengthening of creditor protection improves firms' access to finance (see, e.g., La Porta, Lopez-de-Silanes, and Shleifer, 2008), an improvement in creditor rights may also have adverse effects on firms. For example, Acharya, Sundaram, and John (2011) show that corporations reduce leverage in response to stronger creditor rights to avoid inefficient liquidation in bankruptcy. Acharya, Amihud, and Litov (2011) find that away from distress, firms' investment decisions may be biased towards safer projects to mitigate creditors' liquidation biases. 
von Lilienfeld-Toal, Mookherjee, and Visaria (2012) and Vig (2013) show that a strengthening of creditor rights may reduce debtors' welfare, even if the supply of credit increases.

The paper is organized as follows. Section 2 outlines the model and derives testable predictions. Section 3 describes the data and discusses our index of debt enforcement and the measures for investment, asset sales, and firm risk. Section 4 presents our main empirical results. Section 5 implements a difference-in-differences analysis around a few bankruptcy reforms that weaken the ability of creditors to enforce debt payments. Section 6 presents robustness tests. Section 7 concludes.

\section{Theory and hypotheses}

\subsection{Debt enforcement, investment, and asset sales}

This section presents a simple model that illustrates the effects of debt enforcement in default on shareholder-debtholder conflicts and investment and risk choices. To do so, we consider a two-period version of the Fan and Sundaresan (2000) model that we augment with investment decisions. ${ }^{1}$ Specifically, we consider a firm with assets in place and risky debt outstanding. The value of assets at time $t$ is denoted by $V_{t}$. The return on the firm's assets is governed by a binomial process, so that in each period the asset value can increase by a factor $z>1$ with (risk-neutral) probability $p=\frac{1-z^{-1}}{z-z^{-1}}$ or decrease by a factor $z^{-1}<1$ with probability $1-p$, where we assume for simplicity that the risk-free rate is zero. In addition to its assets in place, the firm has a growth option that, if undertaken, increases asset value by a factor $g$ from $V_{t}$ to $V_{t}(1+g)$. The cost of investment is $I>0$, to be paid by shareholders at time $t=0$. The investment pays off at $t=2$ when the asset value $V_{2}$ can take three values: $z^{2} V_{0}, V_{0}$, and $z^{-2} V_{0}$. These assumptions imply that the increase in firm value from investment is given by

$$
\mathbb{E}\left[g V_{2}\right]=p^{2} g z^{2} V_{0}+2 p(1-p) g V_{0}+(1-p)^{2} g z^{-2} V_{0}=g V_{0}
$$

\footnotetext{
${ }^{1}$ While our results do not depend on the number of periods, we need at least two periods to have three states on the final date, allowing us to examine the effects of default risk on investment and risk choices.
} 
showing that, without risky debt, it is optimal for shareholders to invest if $V_{0} \geq \frac{I}{g}$.

The firm has risky debt outstanding with promised payment $D$ at time $t=2$. To examine the effects of risky debt and default risk on investment, we consider two alternative scenarios. In the first scenario, which we call "low leverage scenario," we assume that $D=\underline{D}$ with

$$
V_{0}>\underline{D}>(1+g) z^{-2} V_{0}
$$

so that the firm only defaults in the bottom most node of the tree, with probability $(1-p)^{2}$. In the second scenario, which we call "high leverage scenario," we assume that $D=\bar{D}$ with

$$
z^{2} V_{0}>\bar{D}>(1+g) V_{0}
$$

so that the firm defaults in the two lowest nodes, with probability $2 p(1-p)+(1-p)^{2}$.

Suppose first that creditor rights are perfectly enforced in default so that debtholders get all of the firm's assets in default. In the high leverage scenario, the default probability is $2 p(1-p)+(1-p)^{2}$ and shareholders invest if $g p^{2} z^{2} V_{0}>I$ or if

$$
V_{0} \geq \bar{V} \equiv \frac{I}{g p^{2} z^{2}}=\left(\frac{z-z^{-1}}{z-1}\right)^{2} \frac{I}{g}>\frac{I}{g}
$$

In the low leverage scenario, the default probability is $(1-p)^{2}$ and shareholders invest if

$$
V_{0} \geq \underline{V} \equiv \frac{I}{g\left[p^{2} z^{2}+2 p(1-p)\right]}=\frac{I}{g\left[1-(1-p)^{2} z^{-2}\right]}>\frac{I}{g}
$$

Since $p \in(0,1)$ and $z>1$, we have $\bar{V}>\underline{V}>\frac{I}{g}$. It follows that with risky debt and perfect enforcement of debt obligations in default there is underinvestment, as shareholders do not invest when either $V_{0} \in\left[I / g, \underline{V}\right.$ ) (in the low leverage scenario) or $V_{0} \in[I / g, \bar{V}$ ) (in the high leverage scenario). Indeed, in such instances, the NPV of the growth option is less than the potential wealth transfer to debtholders. ${ }^{2}$ In addition, underinvestment increases with the probability of default, as shown by the ordering of the investment thresholds.

\footnotetext{
${ }^{2}$ To see why, suppose we are in the low leverage scenario and $V_{0}=\frac{I}{g}$. In this case, the NPV of the project to the firm is zero but debt value increases by $(1-p)^{2} g z^{-2} V_{0}$ following investment, implying that the wealth
} 
Suppose now that debt can be renegotiated in default due to imperfect debt enforcement and that shareholders can appropriate a fraction $1-\eta$ of firm value, where $\eta \in[0,1]$ captures debt enforcement in default. When $\eta=1$, creditor rights are perfectly enforced implying that shareholders get nothing in default. When $\eta<1$, debt enforcement is imperfect, leading to a positive payoff to shareholders in default. We show below that variation in debt enforcement should lead to variation in investment and risk taking.

To see this, note that in the high leverage scenario, the probability of default is again $2 p(1-p)+(1-p)^{2}$ but shareholders invest if

$$
V_{0} \geq \bar{V}_{R}(\eta) \equiv \frac{I}{g\left[p^{2} z^{2}+2 p(1-p)(1-\eta)+(1-p)^{2}(1-\eta) z^{-2}\right]}
$$

In the low leverage scenario, the default probability is again $(1-p)^{2}$ but shareholders invest if

$$
V_{0} \geq \underline{V}_{R}(\eta) \equiv \frac{I}{g\left[p^{2} z^{2}+2 p(1-p)+(1-p)^{2}(1-\eta) z^{-2}\right]}
$$

Eq. (2) and (3) show that shareholders' investment behavior reflects their expected recovery in default, which depends on debt enforcement. Because $\eta \in[0,1]$ and $z>1$, we have $\frac{I}{g} \leq \underline{V}_{R}(\eta) \leq \bar{V}_{R}(\eta)$, with strict inequalities when $\eta<1$. That is, shareholders' incentives to invest decrease with the probability of default, as shareholders do not invest when either $V_{0} \in\left[I / g, \underline{V}_{R}(\eta)\right.$ ) (in the low leverage scenario) or $V_{0} \in\left[I / g, \bar{V}_{R}(\eta)\right.$ ) (in the high leverage scenario). Eq. (2) and (3) also show that we have $\underline{V}_{R}(\eta)<\underline{V}$ and $\bar{V}_{R}(\eta)<\bar{V}$ when $\eta<1$ so that imperfect debt enforcement mitigates underinvestment incentives. Lastly, when $\eta=0$, we have $\underline{V}_{R}(0)=\bar{V}_{R}(0)=\frac{I}{g}$ so that there is no underinvestment. Our model therefore reproduces Myers's (1977) main result that firms may reject positive NPV projects whenever some of the benefits of new investment accrue to debtholders by increasing the value of risky debt. Specifically, for underinvestment to arise, we need the default probability to be positive of shareholders decreases by the same amount if the firm invests. When $V_{0} \in[I / g, \underline{V})$, the NPV of investment is positive for the firm but negative for shareholders. When $V_{0}=\underline{V}$, the NPV of investment is positive for the firm and zero for shareholders. When $V_{0}>\underline{V}$, the NPV of investment is positive for the firm and shareholders. 
(necessary condition) and the wealth transfer to debtholders to increase the project's NPV (sufficient condition). The latter condition is satisfied if $V_{0}<\underline{V}_{R}(\eta)$ in the low leverage scenario and if $V_{0}<\bar{V}_{R}(\eta)$ in the high leverage scenario. Our model adds, however, to Myers' predictions by showing that underinvestment distortions are mitigated when debt enforcement in default is imperfect.

Importantly, simple calculations also show that:

$$
\begin{aligned}
\frac{\partial\left(\bar{V}_{R}(\eta) / \underline{V}_{R}(\eta)\right)}{\partial \eta} & =\frac{2 z(1+z)^{2}}{\left((1+z)^{2}-(1+2 z) \eta\right)^{2}}>0 \\
\frac{\partial\left(\left(I /(g(1-\eta)) / \underline{V}_{R}(\eta)\right)\right.}{\partial \eta} & =\frac{z(z+2)}{(1+z)^{2}(1-\eta)^{2}}>0 \\
\frac{\partial\left(\left(I /(g(1-\eta)) / \bar{V}_{R}(\eta)\right)\right.}{\partial \eta} & =\frac{z^{2}}{(1+z)^{2}(1-\eta)^{2}}>0
\end{aligned}
$$

where $I /(g(1-\eta))$ is the investment threshold when the firm defaults with probability 1 at time $t=2$ and the ratio $\bar{V}_{R}(\eta) / \underline{V}_{R}(\eta)$ measures the change in the investment threshold due to a change in the default probability when moving from the low leverage scenario to the high leverage scenario for a given $\eta$. These relations imply that the effect of the firm-specific default probability on investment incentives increases with the degree of debt enforcement. When there is no default risk, shareholders invest if $V_{0} \geq \frac{I}{g}$ and debt enforcement has no bearing on investment. ${ }^{3}$

Summarizing, our simple model shows that (1) firms with a positive default probability may reject positive NPV projects; (2) the effect of the default probability on investment incentives increases with debt enforcement; (3) debt enforcement does not affect investment for firms with zero default probability.

\footnotetext{
${ }^{3}$ When measuring the effect of debt enforcement on the relation between investment incentives and the default probability starting from a scenario in which debt is risk-free, we also have

$$
\frac{\partial\left(\underline{V}_{R}(\eta) /(I / g)\right)}{\partial \eta}>0, \frac{\partial\left(\underline{V}_{R}(\eta) /(I / g)\right)}{\partial \eta}>0 \text { and } \frac{\partial((I /(g(1-\eta)) /(I / g))}{\partial \eta}>0
$$

showing here again that the effect of the firm-specific default probability on investment incentives increases with the degree of debt enforcement.
} 
So far, we have examined the effects of debt enforcement on shareholders' incentives to acquire new assets. Debt enforcement is also important for asset sales. Suppose indeed that the firm can sell a fraction $\theta$ of its assets at time $t=0$ for a price $S$ and that $D=\underline{D}$ (similar arguments can be made if $D=\bar{D})$. The firm will sell the asset if $S>\underline{S}(\eta)$ where

$$
\underline{S}(\eta) \equiv \theta\left\{p^{2}\left[(1+g) z^{2} V_{0}-\underline{D}\right]+2 p(1-p)\left[(1+g) V_{0}-\underline{D}\right]+(1-p)^{2}(1-\eta)(1+g) z^{-2} V_{0}\right\}
$$

where the right-hand side of this equation represents a fraction $\theta$ of the cash flows accruing to shareholders. It is immediate to see that the minimum price $\underline{S}(\eta)$ that leads the firm to sell its assets decreases with debt enforcement and with the default probability. That is, shareholders' incentives to sell assets are distorted by risky debt because of the value that is transferred to debtholders when the firm is in default. This is another form of underinvestment.

\subsection{Debt enforcement and risk-shifting}

Suppose now that shareholders can increase risk just after investing in the project, i.e., engage in asset substitution. ${ }^{4}$ When leverage is low and debt enforcement in default is imperfect, equity value just after investment is given by:

$$
E\left(V_{0} ; \underline{D}\right)=p^{2}\left[(1+g) z^{2} V_{0}-\underline{D}\right]+2 p(1-p)\left[(1+g) V_{0}-\underline{D}\right]+(1-p)^{2}(1-\eta)(1+g) z^{-2} V_{0}
$$

An increase in $z$ corresponds to an increase in the possible spread of values for the project and, therefore, in project risk. Using the definition of the risk-neutral probability of an increase in asset value, we have that:

$$
\frac{\partial E\left(V_{0} ; \underline{D}\right)}{\partial z}=\frac{2\left[\underline{D} z+\eta(1+g) V_{0}\right]}{(1+z)^{3}}>0
$$

in the low leverage case so that:

$$
\frac{\partial^{2} E\left(V_{0} ; \underline{D}\right)}{\partial z \partial \eta}=\frac{2(1+g) V_{0}}{(1+z)^{3}}>0
$$

${ }^{4}$ Risk-shifting can also be analyzed in closed-form in the case of a firm without a growth option, with the same results and empirical implications. See Appendix C for details. 
Eq. (4) shows that, for firms with a positive default probability, shareholders have incentives to increase risk after debt has been issued, a result first uncovered by Jensen and Meckling (1976). This is due to the fact that shareholders own an option to default and that the value of this option increases with asset risk. Eq. (5) shows that by decreasing shareholders' expected recovery in default, stronger debt enforcement increases the convexity of the option payoff and makes it more attractive for shareholders to increase risk. Lastly, simple calculations also show that we have

$$
\frac{\partial^{2} E\left(V_{0} ; \bar{D}\right)}{\partial z \partial \eta}=\frac{2(1+g) z V_{0}}{(1+z)^{3}}>0
$$

in the high leverage case so that

$$
\frac{\frac{\partial^{2} E\left(V_{0} ; \bar{D}\right)}{\partial z \partial \eta}}{\frac{\partial^{2} E\left(V_{0} ; \underline{D}\right)}{\partial z \partial \eta}}=\frac{\frac{2(1+g) z V_{0}}{(1+z)^{3}}}{\frac{2(1+g) V_{0}}{(1+z)^{3}}}=z>1 .
$$

That is, debt enforcement has a greater effect on risk taking when default risk is larger. Lastly, when $D$ is low enough that there is no default risk, equity value after investment is given by $E\left(V_{0} ; D\right)=(1+g) V_{0}-D$ and debt enforcement has no effect on risk taking.

Before turning to the empirical analysis, we summarize below our testable hypotheses:

Hypothesis 1: Investment in leveraged firms subject to default risk should decrease with the firm-specific default probability. The effect of the default probability on investment should be stronger in countries with stricter debt enforcement.

Hypothesis 2: Risk in leveraged firms subject to default risk should increase with the firmspecific default probability. The effect of the default probability on risk should be stronger in countries with stricter debt enforcement.

\section{Data and empirical method}

\subsection{Data}

Our sample covers 41 countries for the period 2000-2010. We collect accounting data in U.S. Dollars from Worldscope and Capital IQ, and stock price data in U.S. Dollars from the 
Center for Research in Security Prices (CRSP) (for U.S. firms) and Datastream (for the rest of the world). We exclude financial services firms (first Standard Industry Classification (SIC) code digit equal to six), utility firms (first two SIC code digits equal to 49), and governmentrelated firms (first SIC code digit equal to 9). We winsorize the variables in our sample at the 1st and 99th percentiles to minimize the effects of outliers or coding errors in Worldscope, Capital IQ, and Datastream. The final sample consists of 18,602 firms.

Data about debt enforcement come from Djankov, Hart, McLiesh, and Shleifer (DHMS, 2008). Other country-specific variables are from the World Bank databases. Appendix A provides a description of the data collection. Table 1 contains the definitions of the variables in the data set.

Insert Table 1 Here

\subsubsection{Debt enforcement}

In the model, a high value of $\eta$ reflects a stricter enforcement of debt contracts via provisions in the bankruptcy procedure that make a successful debt renegotiation in or out-of-court less likely. We measure debt enforcement using the data from the DHMS international survey on debt enforcement procedures. In this survey, attorneys and judges who practice bankruptcy law in 88 countries are asked to describe how an identical case of a firm defaulting on its debt is treated. Based on these responses, DHMS report country-specific measures of the quality of debt enforcement, some of which form the basis of our analysis.

Specifically, we follow Favara, Schroth, and Valta (2012) and define Debt enforcement as the average of 16 binary indicators (zero if no, one if yes) that are likely to strengthen the enforcement of debt contracts in default, mainly via frictions against renegotiations. These indicators include the rights of creditors to seize and sell firm collateral without court approval; to enforce their claims in an out-of-court procedure; to approve the appointment of an insolvency administrator and dismiss it; and to vote directly on the reorganization plan of a defaulting firm. The index also includes information on whether an insolvency procedure cannot be appealed and whether management is automatically dismissed during the resolution of 
the insolvency procedure. As a result, this index captures impediments to shareholders' ability to renege on outstanding debt, whether through a formal insolvency procedure or outside of court. By construction, the Debt enforcement index ranges from zero to one: the higher the score, the stricter debt enforcement and the less likely shareholders will be able to renegotiate debt in default. A detailed description of this index is provided in Appendix B.1.

Insert Table 2 Here

As in Favara, Schroth, and Valta (2012), we impute the DHMS survey results from 2005 to all the years in our sample (2000-2010), assuming that the survey captures the essence of each country's approach to insolvency, which is deeply rooted in persistent economical, political, and societal values. We explore the validity of this assumption in Section 5, where we track all major changes to each country's bankruptcy code in our sample period. While such changes are rare, we conduct in Section 5 a difference-in-differences analysis of firms' behavior around the few cases where the country's bankruptcy code reform changes debt enforcement by making it easier to renegotiate debt. ${ }^{5}$

Table 2 shows that the average value of the Debt enforcement index in our sample is 0.54 , with a standard deviation of 0.25 . The majority of countries in the sample are concentrated around values of 0.45 and 0.58 , including Japan and the U.S. According to the Debt enforcement index, debt is expected to be enforced relatively weakly in countries with a French origin of the legal system, e.g., France, Italy, and the Netherlands. Conversely, debt enforcement is stricter in, e.g., Austria, Finland, or Hungary, as well as Thailand or Turkey. Table 2 also shows that the number of firms varies substantially across countries, with U.S. and Japanese firms respectively accounting for $16 \%$ and $12.6 \%$ of the sample observations. We show below that our results continue to hold when we exclude U.S. and Japanese firms from the sample.

${ }^{5}$ Bankruptcy law reforms until 2004 are tracked by Djankov, McLiesh, and Shleifer (2007), and by the World Bank (www.doingbusiness.org). Within our ten-year sample period, the only major changes in the bankruptcy code that explicitly affected the renegotiability of debt are in France (2005), Brazil (2005), and Italy (2005). Major bankruptcy reforms in Russia (2004) and Spain (2004) are not focused on debt renegotiability. Japan also changed its bankruptcy code in 2000, but the changes were undone in 2002. 


\subsubsection{Default probability}

Conflicts of interest between shareholders and debtholders, and hence underinvestment and risk-shifting distortions, are most prevalent when a firm has risky debt and when there is a significant probability that the firm will default on its debt obligations. To measure the default probability, we rely on the naïve default probability measure of Bharath and Shumway (2008), which is an approximation of the Merton (1974) model. ${ }^{6}$ Bharath and Shumway (2008) show that the naïve default probability performs better at predicting default than the actual Merton (1974) model probability. Moreover, the naïve default probability can be easily computed for our large international panel of firms because it does not rely on credit ratings data. Table 2 shows that the default probability varies significantly within and across countries.

\subsubsection{Investment, asset growth, and risk}

We study the relation between the default probability, its interaction with debt enforcement, and three main outcome variables: Investment, asset sales, and risk. We measure Investment as capital expenditures in year $t$ divided by total assets in year $t-1$. The average investment rate is $5.6 \%$ with a standard deviation of 0.070 .

Because capital expenditures are truncated at zero, they are not informative about whether the firm is selling or buying assets. We use Asset growth as an alternative measure of investment because it can take negative values and, therefore, includes asset sales. We define Asset growth as the growth in total assets from year $t-1$ to year $t$. In the sample, the average asset growth rate is $9.2 \%$ with a standard deviation of $0.257 .{ }^{7}$

\footnotetext{
${ }^{6}$ The naïve default probability approximates the functional form of the Merton default probability, but simplifies the computation of the variables needed as inputs. The two main simplifications are: 1) the expected return on the firm's assets is measured by the firm's stock return over the previous year; 2) total asset volatility is measured as a weighted average of the book debt and market equity volatilities. See Bharath and Shumway (2008, p. 1347) for further details.

${ }^{7}$ Alternative approaches to measure asset sales in the literature include the uses of keyword searches for 'asset,' 'sale,' and 'divestiture' within 8K filings with the Securities and Exchange Commission (SEC) (Lang,
} 
To measure risk, we use three proxies based on the market price of equity. The first risk measure, Equity vol, is equal to the annualized standard deviation of weekly stock returns (Friday-to-Friday) in year $t$ as in Bartram, Brown, and Stulz (2012). ${ }^{8}$ The second risk measure, Idiosyncratic vol, uses idiosyncratic stock return volatility. For every firm in the sample, we regress a firm's weekly stock returns in year $t$ on the lagged, contemporaneous, and lead world market index return and compute Idiosyncratic vol as the annualized standard deviation of the residuals. This measure allows us to test whether shareholders control systematic or idiosyncratic equity volatility in their attempt to increase risk. ${ }^{9}$ The third risk measure, Asset vol, is computed as in Bharath and Shumway (2008) as the average of the annual equity and debt volatilities, weighted by the market equity and debt face values. We also use a risk measure based on accounting information. Notably, following John, Litov, and Yeung (2008), we compute the volatility of the ratio of Earnings before interest, taxes, depreciation, and amortization (EBITDA) to assets over eight years, between years $t$ and $t-7$, requiring at least five available observations. While EBITDA-to-assets vol is a widely used measure of asset risk, it is clearly backward-looking and may not capture the risk associated with shareholders' operational or investment choices.

Poulsen, and Stulz, 1995), reductions in the number of industry segments per firm reported in Compustat (Schlingemann, Stulz, and Walkling, 2002), divestiture data from Securities Data Company (SDC) (Schlingemann, Stulz, and Walkling, 2002) and plant-level data (Yang, 2008). The data required to implement these approaches in our international cross-section are unavailable.

${ }^{8}$ Some stocks in our sample are not frequently traded. Hence, by computing returns based on weekly data, these stocks have zero returns. This computation could bias downwards our volatility estimates. To address this issue, we exclude from the sample all firms with high proportions of zero stock returns. The current sample uses a cutoff of $90 \%$, but the results are robust to lower cutoff levels. The results are also robust to using returns and volatilities based on daily stock prices.

${ }^{9}$ Chen, Strebulaev, Xing, and Zhang (2014) show that idiosyncratic volatility is the best predictor of future stock returns among all the components of total asset volatility. Their interpretation is that, given the choice, shareholders prefer to increase idiosyncratic rather than systematic risk because the latter reduces the stock value and the former does not carry downside market risk. 


\subsubsection{Other firm- and country-level control variables}

Table 3 summarizes all the control variables used in the analysis. For the majority of the variables in the data set, the variation is mostly between rather than within firms. This feature of the data is not surprising for some variables, such as leverage, which are known to have large permanent components (Lemmon, Roberts, and Zender, 2008). Other variables, such as Default probability and Asset growth, exhibit larger within-firm variation.

Insert Table 3 Here

\subsection{Empirical method}

To test our hypotheses, we estimate the following regression model:

$$
\begin{aligned}
& \text { Dependent } \text { variable }_{i, j, c, t} \\
& \qquad \beta_{0}+\beta_{D} \times \text { Default probability }{ }_{i, j, c, t-1}+\beta_{\eta} \times \text { Debt enforcement }_{c} \\
& +\beta_{D \eta} \times \text { Default probability } y_{i, j, c, t-1} \times(\text { Debt enforcement } \\
& c-\overline{D e}) \\
& \\
& +\delta_{t}+\boldsymbol{\beta}_{\text {Control }} \times \text { Controls }_{i, j, c, t-1}+u_{i, j, c, t} .
\end{aligned}
$$

In Eq. (6), the dependent variable is either Investment, Asset growth, or one of the risk measures. We use the subscripts $i$ for firms, $j$ for industries, $c$ for countries, and $t$ for years. Default probability ${ }_{i, j, c, t-1}$ is the lagged default probability, Debt enforcement $t_{c}$ is the countryspecific measure of debt enforcement, and $\overline{D e}$ is its sample mean. Controls $\mathbf{s}_{i, j, c, t-1}$ is a set of predetermined firm and country characteristics that are likely to affect our dependent variables. We control for firms' growth opportunities with the market-to-book ratio (Market-tobook ratio), for the available cash flow (Cash flow-to-assets ratio), for size (log(Total assets)), and for profitability (EBITDA-to-assets). We also include country-level cyclical factors influencing investment, growth opportunities, and risk, such as the log of Gross Domestic Product (GDP) per capita, GDP growth, and Stockmarket cap to GDP. We include year fixed effects $\left(\delta_{t}\right)$ to control for time-varying factors common to all firms. We cluster standard errors at the country level. 
According to Hypotheses 1 and 2, the main parameters of interest in our empirical analysis are $\beta_{D}$ and $\beta_{D \eta}$. The parameter $\beta_{D}$ measures the association between the firm's default probability and the dependent variable evaluated at the sample mean of Debt enforcement. We expect $\beta_{D}$ to be negative for investment and asset growth, and positive for risk. $\beta_{D \eta}$ measures, instead, how the relation between a firm's investment or risk and its default probability vary with the country-specific measure of debt enforcement. We expect this parameter to be negative for the investment and asset growth regressions and positive for the risk regressions.

Our benchmark regression model is estimated with either country and industry fixed effects or firm fixed effects. These fixed effects absorb time-invariant differences across industries and countries or firms, and minimize the concern that other unobserved factors may drive the results. For example, country fixed effects account for other time-invariant country-specific factors, such as the efficiency of the judicial system or the rule of law. Firm fixed effects mitigate the concern that unobserved firm-level attributes, provided they are time-invarying, affect the firms' default probability as well as their investment and risk decisions. Adding these fixed effects causes the country-specific Debt enforcement $t_{c}$ variable to drop out. Our model predicts that this variable's coefficient, $\beta_{\eta}$, should be zero when the firm's probability of default is zero. We test this additional implication as a robustness test in a pooled Ordinary Least Squares (OLS) regression, with the caveat that the OLS estimate of $\beta_{\eta}$ might also capture the effect of other unobservable country characteristics, unrelated to debt enforcement.

\section{Results}

\subsection{Investment}

Table 4 presents the main results for investment. Our main interest is on the coefficients of Default probability and the interaction term Default probability $\times$ Debt enforcement. Columns 1 and 2 show the estimates for our benchmark specification with industry and country, or firm fixed effects, respectively.

Insert Table 4 Here 
As predicted, both Default probability and its interaction with Debt enforcement correlate negatively and significantly with investment rates. ${ }^{10}$ To evaluate the economic significance of our estimates, we compute the implied difference between the expected investment rates of firms that are similar, given our control variables, but operate in countries with different values of the Debt enforcement index. We evaluate the statistic

$$
\begin{aligned}
\Delta E(\text { Investment }) \equiv & E\left(\text { Investment } \mid \eta_{0}, .\right)-E\left(\text { Investment } \mid \eta_{1}, .\right) \\
= & \hat{\beta}_{\eta} \times\left(\eta_{0}-\eta_{1}\right)+ \\
& \hat{\beta}_{D \eta} \times\left(\text { Default probability } y_{0} \times \eta_{0}-\text { Default probability }{ }_{1} \times \eta_{1}\right) .
\end{aligned}
$$

In this equation, $\eta_{0}$ and $\eta_{1}$ are any two given values of the Debt enforcement index. Default probability $_{i}$ is the average default probability for all firms with a default probability higher than the third quartile breakpoint in countries where $\eta=\eta_{i}$. Table 4 reports this statistic, comparing countries where debt enforcement is weakest $\left(\eta_{0}=0\right.$, say China) and strongest $\left(\eta_{1}=1\right.$, say Australia). Accounting for unobservable industry and country or firm fixed effects, the differences exceed $14 \%$ of the average investment ratio. ${ }^{11}$

Column 3 reports the results of a pooled OLS regression. This regression allows us to measure the correlation between Debt enforcement and investment when the probability of default is zero. As shown, Debt enforcement does not correlate with investment directly, but only via its interaction with Default probability. This finding reassures us that our index of debt enforcement does not proxy for other country characteristics that affect investment and are unrelated to shareholders' expected recovery in default. If this were the case, Debt enforcement could also be correlated with investment unconditionally of firms' default probabilities.

Lastly, Erickson and Whited (2000) show that the error in the market-to-book ratio ('av-

\footnotetext{
${ }^{10}$ The coefficients of the control variables have the expected sign. While predetermined, some of the control variables used in all our specifications are endogenous, though standard in the corporate finance and investment literature. The estimated coefficient of the interaction between Default probability and Debt enforcement actually increases if we exclude these control variables (not reported).

${ }^{11}$ The stability of the interaction effects in columns 1 and 2 suggests that unobservable factors correlated with country or firm fixed effects are unlikely to bias our results.
} 
erage $Q^{\prime}$ ) as a proxy for marginal $q$ may bias the estimates in the investment regressions. Following Erickson, Jiang, and Whited (2014), we use the fifth-order linear cumulants estimator assuming measurement error in Market-to-book ratio and Cash flow-to-assets. Column 4 shows that our results are robust to this correction. ${ }^{12}$

Overall, the results in Table 4 show that, even after controlling for observable firm and country characteristics and for unobservable fixed differences in investment across industries, countries, and firms, investment ratios among the relatively more distressed firms are significantly lower in countries where the bankruptcy procedure favors strict debt enforcement.

Becker and Stromberg (2012) estimate that a 1991 Delaware bankruptcy ruling, which established stronger managerial fiduciary duties towards creditors, increased investment for firms close to insolvency. They interpret this finding as evidence that a transfer of control rights from debtors to creditors mitigates the distortions due to debt overhang. Our results suggest that increasing shareholders' expected recovery in default may also mitigate the distortions caused by risky debt. Because imperfect debt enforcement in default in fact may increase the cash flow to both shareholders and creditors by reducing default costs, ${ }^{13}$ the findings in these two studies suggest that legal institutions can improve efficiency near default by aligning shareholders' incentives with creditors' interests.

\subsection{Asset growth}

We use asset growth as an alternative measure of investment that is also indicative of asset sales, and estimate the same specifications as before, but with Asset growth as a dependent

\footnotetext{
${ }^{12}$ Our results are also robust up to the eighth-order estimator, or to allowing for measurement error in average $Q$ (Market-to-book), profitability (EBITDA-to-assets), and the probability of default (DP).

${ }^{13}$ Fan and Sundaresan (2000), François and Morellec (2004), and Davydenko and Strebulaev (2007) show, for example, that this is the case if liquidation entails costs, and an imperfect enforcement of debt contracts allows the firm to avoid costly liquidation. There exists a large empirical literature documenting significant liquidation costs both in the U.S. (see, e.g., Warner, 1977; Andrade and Kaplan, 1998; Davydenko, Strebulaev, and Zhao, 2012; or Glover, 2016) and outside the U.S. (see, e.g., Gungoraydinoglu and Oztekin, 2011).
} 
variable. Table 5 presents the results.

Insert Table 5 Here

Columns 1 and 2 show that Asset growth and Default probability are on average negatively correlated across countries. Moreover, asset growth is significantly lower for distressed firms in countries with stricter debt enforcement. Column 3 reports the same results for the pooled OLS regression. Column 4 corrects for measurement error in Market-to-book ratio and Cash flow-to-assets using a fifth-order cumulants estimator. In all columns, the coefficients of Default probability and of the interaction term Default probability $\times$ Debt enforcement are negative and statistically significant, with the exception of Default probability in columns 2 and 4.

Economically, the asset growth rate differences between firms in countries with strongest versus weakest debt enforcement vary between $43 \%$ and $89 \%$ of the average asset growth rate across all countries. Our estimates also suggest that Debt enforcement is associated with Asset growth only through its interaction with the default probability - the OLS estimate of $\beta_{\eta}$ is not significantly different from zero in column 3. Overall, the results in Table 5 provide support for our hypothesis on the effects of debt enforcement on firms' investment decisions.

\subsection{Risk}

Table 6 shows the estimates of the risk specification using our four different proxies for risk. In Panel A, columns 1 to 3 show the results for Equity vol, and columns 4 to 6 for Idiosyncratic vol. In Panel B, columns 1 to 3 report the results for total Asset vol, and columns 4 to 6 for EBITDA-to-assets vol. Across all our specifications, we find that Default probability and the interaction between Default probability and Debt enforcement have a positive coefficient, irrespective of the risk proxy. Except for the specification in column 4 of Panel B, the estimates are all statistically significant. As with investment and asset growth, our measure of debt enforcement explains a large proportion of the covariation between risk variables and the probability of default. Additionally, the OLS estimates of the correlation between risk and 
Debt enforcement when Default probability equals zero are not statistically different from zero for all risk variables but EBITDA-to-assets vol.

Insert Table 6 Here

In terms of economic significance, the difference between the average Equity vol of a firm with high default probability (i.e., higher than the third quartile breakpoint of the estimation sample), in a country where the Debt enforcement index equals one and the Equity vol of a similar firm in a country where the Debt enforcement index equals zero ranges between $35 \%$ and $44 \%$ of the average Equity vol. We find similarly strong economic magnitudes for Asset vol and Idiosyncratic vol. In the following, we only report results based on Equity vol and Idiosyncratic vol. We obtain similar results when using Asset vol or EBITDA-to-assets vol.

Acharya, Amihud, and Litov (2011) find that stronger creditor rights reduce corporate risk taking by estimating the correlation between the ex ante protection of creditor rights, as measured by the index of La Porta, Lopez-de-Silanes, Shleifer, and Vishny (1998), and corporate risk, as measured by firms' cash flow variability and risk-reducing investments such as diversifying acquisitions. Our findings that Debt enforcement increases the sensitivity of firm risk to its default probability are obtained using an index of creditor rights that reflects how the law is expected to be enforced in practice, as opposed to how it is written on the books, and proxies of firm risk based on the market price of equity. Section 6.1 discusses in more detail the difference between the two indices of creditor rights.

\section{Bankruptcy code reforms}

In this section, we exploit the reforms to the bankruptcy codes in different countries to compare the behavior of firms before and after such changes using a difference-in-differences analysis. First, we test our theory using the bankruptcy law changes that affected debt enforcement by easing the renegotiability of debt in our sample of countries between 2000 and 2010: the reforms of France, Italy, and Brazil in 2005. Second, we test the theory outside our sample period with a well known major change to the renegotiability of debt in the U.S.: the 
1978 Bankruptcy Reform Act. The goal of these additional tests is to verify the cross-country results in a setting that, by design, reduces the concern that our results may be driven by unobserved country characteristics.

\subsection{Bankruptcy code reforms in France, Italy, and Brazil}

While there are a few bankruptcy law reforms during our sample period, most of these reforms do not change provisions in the bankruptcy code related to the enforcement of debt contracts. They have much broader scope and typically aim at improving the overall efficiency of the bankruptcy procedure. ${ }^{14}$

We are able to identify three bankruptcy code reforms in our sample of 41 countries that change debt enforcement by easing the renegotiability of debt: France, Italy, and Brazil. ${ }^{15}$ In 2005, France added to its bankruptcy law a reorganization procedure inspired by the U.S.'s Chapter 11 ("Sauvegarde de l'entreprise"). The main change was to allow management to retain control of the distressed company, and the goal was to facilitate debt renegotiations, explicitly recognizing that creditors may benefit from transferring some value and control to managers and shareholders (Weber, 2005).

As in France, the reform in Italy in 2005 aimed at facilitating debt renegotiations while protecting debtors (see Rodano, Serrano-Velarde, and Tarantino, 2016). Rodano et al. (2016) show that the value of debt restructured in- or out-of-court significantly increased after this reform was passed. Similarly, Brazil's new bankruptcy law in 2005 was inspired by Chapters 7 and 11 of the U.S. bankruptcy code [see Alencar and Ponticelli (2016) for a detailed discussion]. The new law introduced automatic stay on all litigations against the debtor and made it easier for debtors to initiate debt renegotiation. While the overall reform was much broader, it arguably also weakened debt enforcement.

\footnotetext{
${ }^{14}$ Examples are the reforms undertaken in Poland between 2004 to 2007, which involved changes to improve the operations of the courts, or in Peru in 2006, which expanded the pool of assets usable as collateral.

${ }^{15}$ According to Djankov, McLiesh, and Shleifer (2007), Spain and Russia had bankruptcy reforms in 2004 that increased the creditor rights index by one point. As for Poland, the reforms affected many dimensions of the bankruptcy code. Hence, we exclude these two countries from the following analysis.
} 
For each country, we focus on the behavior of firms from three years before to three years after each reform, that is, we use yearly observations from 2002 to 2008. Following the predictions of the model, we expect that firms with a high default probability modify their investment and risk after the reform, while firms with a low default probability do not change investment and risk. Therefore, we distinguish between firms that should be affected by the reform and firms that should not be affected by conditioning on the firm's default probability before the reform. We define the variable High default probability $y_{i}$ that equals one if the firm's default probability at the end of 2002 is above the second tercile breakpoint of

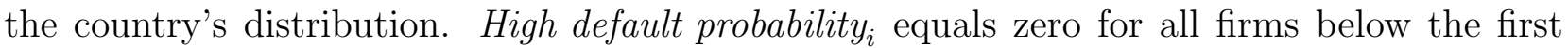
tercile breakpoint of the 2002 default probability distribution. ${ }^{16}$ In the empirical model, we can think of firms with a high default probability as firms treated by the reform, while the low default probability firms are the control firms.

To study the effects of the reforms on investment, asset growth, and risk, we estimate the following differences-in-differences specification:

$$
\begin{aligned}
{\text { Dependent } \text { variable }_{i, t}=\alpha_{i}} & +\delta_{t}+\boldsymbol{\beta}_{\text {Control }} \times \text { Controls }_{i, t-1} \\
& +\beta_{P D} \times \text { POST } \times \text { High default probability } \text { prof }_{i, t} .
\end{aligned}
$$

The dependent variable in Eq. (8) is Investment, Asset growth, or either of the risk measures. POST equals zero until 2004 and one thereafter, indicating that debt becomes more easily renegotiable. A POST dummy equal to one is thus consistent with a lower value of Debt enforcement in our previous tests. The parameter of interest is $\beta_{P D}$, which measures the average change in investment, asset growth, or risk of firms with a high default probability after the bankruptcy code reforms (the treatment group), relative to firms with a low default probability (the control group). Given that debt is easier to renegotiate after each reform, we predict that $\beta_{P D}$ should be positive for investment and asset growth and negative for risk.

Since firms may not be randomly assigned to the exposure groups, we control for the same time-varying observable firm characteristics as in the main specification (6). We also include

\footnotetext{
${ }^{16}$ The results are quantitatively similar if we split the sample at the median or at the first and third quartile breakpoints. The results are also similar if we only include observations from 2003 to 2007, i.e., if we perform the tests using data that start two years before and end two years after the reform.
} 
firm fixed effects $\left(\alpha_{i}\right)$ to absorb time-invariant differences across firms and year fixed effects $\left(\delta_{t}\right)$ to control for time-varying factors common to all firms. Finally, we cluster standard errors at the firm level because firms' investment and risk choices may be correlated over time.

Insert Table 7 Here

Panel A of Table 7 presents the results. Columns 1 and 2 show that the coefficient estimate of POST $\times$ High default probability is statistically and economically significant. Economically, high default probability firms increase their investment rates by 1.6 to 1.7 percentage points after the reforms relative to low default probability firms. Similarly, asset growth rates of high default probability firms increase on average by 8.0 to 11.9 percentage points compared to those of low default probability firms (columns 3 and 4). Finally, columns 5 to 8 show that equity volatility and idiosyncratic volatility decrease after the reform for firms with a high default probability relative to those with a low default probability. In all cases, the coefficient

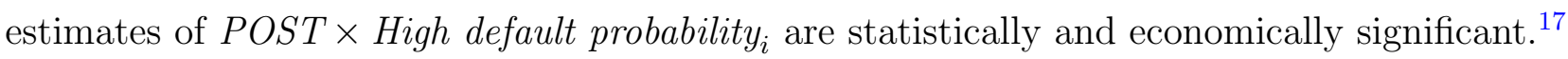
That is, our main theoretical predictions are also supported for the cases in our sample where bankruptcy laws changed to increase the renegotiability of debt.

Insert Figure 1 Here

The core assumption to identify the treatment effect in a differences-in-differences regression is that, in the absence of treatment, there is no pre-existing differential trend between treated and control firms. Any difference in observed trends after treatment are assumed to arise because of treatment. Fig. 1 plots the year-by-year difference in investment, asset growth, and risk between high and low default probability firms relative to the year 2002 (event year -3). The figure shows that before the bankruptcy reforms in 2005 (event year 0 ), the average differences in investment, asset growth, and risk between high and low default probability firms are not statistically different from those in 2002 (year $t-3$ ), suggesting that

\footnotetext{
${ }^{17}$ We have also performed this analysis using a continuous measure of default probability, as done in Tables 4,5 , and 6 . We obtain similar results.
} 
trends in outcomes for treatment and control groups prior to treatment were the same, consistent with the parallel trends assumption. We only observe statistically significant differential investment rates, asset growth, and risk after the bankruptcy reform.

\subsection{The US Bankruptcy Reform Act of 1978}

In the U.S., the Bankruptcy Reform Act (BRA) made three major changes to Chapter 11 of the U.S. bankruptcy code, starting in October 1979 (see Hackbarth, Haselman, and Schoenherr, 2015). First, it imposed court-mandated reorganizations ('cramdowns') in case of disagreement by shareholders and creditors (White, 1989; and Klee, 1979). Second, it lifted the insolvency requirement to file for a reorganization. Third, it decreased the proportion of votes needed to approve a reorganization plan. Overall, the BRA made debt renegotiations more attractive to creditors and shareholders, as the threat of voluntary Chapter 11 filing became a strategic tool for shareholders to extract rents from creditors. As a result, shareholders of financially distressed firms achieved higher concessions from creditors in out-of-court restructurings (Franks and Torous, 1994), as well as higher deviations from the Absolute Priority Rule in Chapter 11 (see Franks and Torous, 1989; Eberhart, Moore, and Roenfeldt, 1990). Further, equity returns decreased because of a lower required distress premium (Hackbarth, Haselmann, and Schoenherr, 2015).

The BRA is also well suited to test our hypotheses because it was designed to encourage debt renegotiation and shifted the bargaining power in reorganizations towards shareholders. Moreover, this well known reform allows us to validate our main results in a different sample period, while keeping the other institutional characteristics constant.

We conduct a differences-in-differences analysis around the BRA as for the reforms in France, Italy, and Brazil. We include in the analysis three years before and three years after

the reform year 1979, i.e., the years from 1976 to 1982. All variables are defined and computed as in the cross-country analysis, except that we use Compustat data because Worldscope's coverage starts only in 1990. The reform indicator POST equals zero until 1978 and one

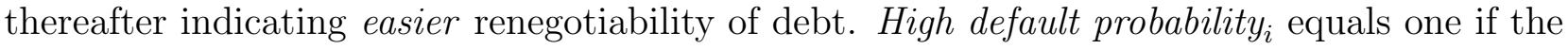
firm's default probability at the end of 1976 is above the second tercile breakpoint of the 1976 (pre-reform) distribution, and zero if it is below the first tercile breakpoint. 
As shown in Panel B of Table 7, investment and asset growth increase while risk decreases post-BRA for firms with a high default probability relative to firms with a low default probability. All coefficients are statistically and economically significant. We obtain similar results when using a continuous measure of default probability, as in Tables 4, 5, and 6 .

Insert Figure 2 Here

As done for the reforms in France, Italy, and Brazil, Fig. 2 plots the year-by-year difference in investment, asset growth, and risk between high and low default probability firms for the BRA relative to the year 1976. The figure shows that high and low default probability firms have similar changes in investment rates, asset growth, and risk before the BRA, and that these changes only start diverging post-BRA.

\section{Robustness analysis}

\subsection{Ex ante creditor rights and debt enforcement}

A large empirical literature, surveyed by La Porta, Lopez-de-Silanes, and Shleifer (2008), studies the effects of creditor protection on corporate investment and financing policies. Most papers in this literature measure the variation in creditor protection across countries with the creditor rights index of La Porta, Lopez-de-Silanes, Shleifer, and Vishny (LLSV, 1998). The LLSV index varies from 0 (weakest) to 4 (strongest) and aggregates four binary indicators of the power of creditors in bankruptcy to (i) approve a debtor's filing for reorganization; (ii) seize collateral after a reorganization petition is approved; (iii) be paid first out of the liquidation proceeds; and (iv) replace the incumbent manager during the reorganization.

The Debt enforcement index used in our empirical analysis differs from the LLSV index because it builds on the detailed narratives provided by law practitioners in the DHMS survey about the debt enforcement procedure that is actually used in each country. As such, our index suffers less from the common criticism to the LLSV index, that the strength of creditor rights in bankruptcy is best measured by how the law is expected to be enforced in practice, as opposed to how it is written on the books. 
For example, with reference to the measurement of creditor rights in India, Vig (2013) writes "Although India ranks quite high in terms of the LLSV creditor rights index and attains a maximum score of 4 , the enforcement of creditor rights has been seen as a major impediment to lending in India. Historically, the judicial process was extremely rigid, marked by bureaucratic delays, and it took a long time before creditors could access collateral." In our sample of countries, the correlation between the Debt enforcement index and the LLSV index is about 0.40. Belgium, Canada, Switzerland, Finland, Hungary, Ireland, Japan, Peru, Philippines, Portugal, Sweden, Thailand, Turkey, Taiwan, and USA have a debt enforcement index above the sample median and a LLSV index below the sample median. In contrast, Germany, Denmark, Korea, the Netherlands, and South Africa have a debt enforcement index below the sample median, and a LLSV index above the sample median.

To test our claim that what matters for investment and risk choices is debt enforcement in default, Table 8 reports the estimates of our benchmark investment, asset growth, and risk regressions using the LLSV index of creditor rights instead of our index of Debt enforcement. If our results were driven by cross-country differences in the ex ante protection of creditor rights, rather that frictions in the enforceability of debt contracts in default, we would expect the interaction between Default probability and the LLSV creditor rights index (Creditor rights) to be correlated with the firms' investment and risk variables across countries.

Insert Table 8 Here

Columns 1 to 4 of Table 8 show that this is not the case: controlling for country and industry fixed effects, firms' investment and risk are significantly related to firms' default probability. However, the interaction of Default probability with Creditor rights is never statistically significant, suggesting that the relation between investment or risk and the default probability is not significantly related to cross-country differences in the LLSV index of ex ante protection of creditor rights. The results reported in these columns are robust to using alternative fixed effects estimators. 


\subsection{Extended debt enforcement index}

Our tests so far use a measure of debt enforcement based on the 16 characteristics out of 24 reported in the DHMS survey that, according to Favara, Schroth, and Valta (2012), are clear indicators of whether debt can be successfully renegotiated. In this section, we test the robustness of our results to using an extended debt enforcement index that also includes the remaining eight characteristics from the DHMS survey. As with the original Debt enforcement index, each additional binary indicator in the extended index takes a value of one

if it strengthens debt enforcement. Appendix B.2 describes these variables and the extended index in detail.

Insert Table 9 Here

Columns 1 to 4 of Table 9 show the estimates of our benchmark investment and risk regressions when using the extended debt enforcement index. We obtain the same qualitative results as before, if quantitatively stronger.

\subsection{Other robustness checks}

Columns 5 to 8 of Table 9 show the estimates of our benchmark investment and risk regressions using a subsample that excludes U.S. and Japanese firms. The results are not affected by the exclusion of such firms, even though they account for almost $30 \%$ of the firms in the sample.

In additional unreported tests we replace the firm's Default probability measure, which is Bharath and Shumway's (2008) approximation of the Merton distance-to-default model, with the Altman's Z-score. We obtain similar results.

\section{Conclusion}

We argue that the prospect of an imperfect enforcement of debt contracts in default reduces shareholder-debtholder conflicts and induces leveraged firms to invest more and take on less 
risk as they approach financial distress. To test these predictions, we use a large panel of firms from 41 countries with heterogeneous debt enforcement characteristics. We find that debt renegotiation frictions that strengthen the enforcement of debt contracts relate to investment and firm risk through their interactions with the firm-specific probability of default. The results suggest that the possibility of an imperfect enforcement of debt contracts, which likely increases shareholders' expected recovery in default, decreases the underinvestment and asset substitution distortions caused by agency conflicts near insolvency.

Previous literature has found that some forms of strengthening of creditor rights may lead to smaller debt overhang distortions near default. Our study shows that these distortions may also be mitigated by a weakening of the enforceability of debt contracts in default. There are two take-aways from our analysis. First, the policy choices of firms near default depend on the different ways creditor rights may be enforced in practice. Second, the relative benefits and costs of pro-creditor and pro-debtor approaches to bankruptcy regulation, and their effects on investment policy, should be studied in future research. 


\section{Appendix A. Data set}

We start with all the countries in the DHMS survey that are also covered by Worldscope, Capital IQ, and Datastream. For every firm in each country, we download annual accounting variables, in USD, from Worldscope, and weekly and daily price data, in USD, from Datas-

tream. For U.S. firms, we download price data from CRSP. We match the firm-level data with several country-specific institutional variables that come from the World Bank. We drop some countries because of the low number of observations (Colombia, Czech Republic, Egypt, and Venezuela), and because the institutional variables are not available (India, Pakistan, and Zimbabwe). We also drop firm-years with negative or zero total assets or sales, and firm-years for which the (absolute value of) negative EBITDA is larger than total assets, as in Bris, Koskinen, and Nilsson (2009). The results do not depend on this exclusion because it involves very few firm-years. We end up with a sample of firms from 41 countries, including all Organisation for Economic Co-operation and Development (OECD), some Latin American, Middle Eastern, and Asian countries. Our panel is unbalanced because we do not require that the firms exist for the whole sample period.

\section{Appendix B. Debt enforcement index}

\section{B.1. Baseline debt enforcement index}

The construction of the Debt enforcement index follows the paper by Favara, Schroth, and Valta (2012) and is based on the DHMS survey data. The individual data items are available on Andrei Shleifer's web page. The index measures the degree of enforcement of debt contracts in default and is based on 16 individual indicators. The measure of debt enforcement in the model is a continuous measure that takes values between zero and one. Accordingly, the Debt enforcement index is the average of the following non-missing binary (zero if no, one if yes) indicators where the variable names in parentheses correspond to the names in the DHMS data set (when a variable $X$ decreases debt enforcement, we take $1-X$ ):

1. Out of court seizure and sale: Secured creditors may seize and sell their collateral without court approval (ooc);

2. No judge for enforcement: Secured creditors may enforce their security either in or out of court (sumjud);

3. Floating charge: The entire business's assets can be pledged as collateral (floating);

4. Case proceeds on appeal of insolvency: An insolvency order cannot be appealed at all (apporde);

5. Case proceeds on appeal of liquidation: A liquidation order cannot be appealed at all (appsal); 
6. Case proceeds on claim amount dispute: An insolvency case is suspended until the resolution of the appeal (1-disclai);

7. Reorganization attempt required: The firm may enter liquidation without attempting reorganization (1-attemreo);

8. Automatic trigger for liquidation: An automatic trigger mechanism can initiate insolvency (trigliq);

9. Automatic stay on enforcement: Secured creditors may enforce their security upon commencement of the insolvency proceedings (1-scsstay);

10. Automatic stay on lawsuits: Secured creditors may enforce their security in lawsuits (1-lawsc);

11. Firm must cease operating: A defaulting firm must cease operations upon commencement of insolvency proceedings (opceas);

12. Management remains: Management does not remain in control of decisions during insolvency proceedings (1-mancont);

13. Creditor approves administrator: Secured creditors have the right to approve the appointment of the insolvency administrator (whoapp);

14. Creditor dismisses administrator: Secured creditors may dismiss the insolvency administrator (dismiss);

15. Creditor vote directly: Secured creditors vote directly on the reorganization plan (scvotdir);

16. Proof of reorganization prospects: Firm must submit proof of reorganization prospects before reorganization proceedings may commence (proofreo).

\section{B.2. Additional characteristics from the DHMS survey and extended index}

Our baseline Debt enforcement index is based on 16 individual indicators, out of 24 indicators reported by DHMS. This baseline index does not include all 24 indicators, as for eight of them it was not clear to us whether they made debt enforcement in default easier or more difficult. In a robustness test, we use an extended debt enforcement index that also includes the following (remaining) characteristics from the DHMS survey, in addition to the 16 individual indicators of our baseline Debt enforcement index.

1. Statutory time limits on appeals: Time limits on appeals are probably good for creditors to enforce their claim (apptime);

2. Restrictions on dismissals: The firm is not restricted from dismissing employees upon initiation of insolvency proceedings (empres); 
3. Contracts may be rescinded: Suppliers and customers may rescind contracts without penalty upon initiation of insolvency proceedings (supresc);

4. Specialized court: The authority with jurisdiction is either a specialized bankruptcy court or a specialized bankruptcy administrative authority (spec);

5. Administrator paid on market value: The insolvency admministrator is remunerated based on the market value of the insolvency estate (mktval);

6. Same judge for claim amount dispute: An appeal of the amount of the claim is handled by the same judge supervising the insolvency case (disju);

7. Same judge for appeal of insolvency: An appeal of the initiation of the insolvency case is handled by the same judge supervising the insolvency case (orderju);

8. Same judge for appeal of liquidation: An appeal of the order to liquidate is handled by the same judge supervising the insolvency case (saleju).

Some of these variables are difficult to classify as pro-debtor or pro-creditor, for example, those related to judges. Results are similar if we exclude the last three indicators from the list above.

\section{Appendix C. Debt enforcement and risk taking without investment}

Suppose now that there is no investment opportunity but that shareholders can increase risk after debt has been issued. In this case, equity value is given by

$$
E\left(V_{0} ; \underline{D}\right)=p^{2}\left(z^{2} V_{0}-\underline{D}\right)+2 p(1-p)\left(V_{0}-\underline{D}\right)+(1-p)^{2}(1-\eta) z^{-2} V_{0} .
$$

Using the definition of the risk-neutral probability of an increase in asset value, we have that:

$$
\frac{\partial E\left(V_{0} ; \underline{D}\right)}{\partial z}=\frac{2\left[\underline{D} z+\eta V_{0}\right]}{(1+z)^{3}}>0,
$$

in the low leverage case so that:

$$
\frac{\partial^{2} E\left(V_{0} ; \underline{D}\right)}{\partial z \partial \eta}=\frac{2 V_{0}}{(1+z)^{3}}>0 .
$$

Simple calculations also show that we have

$$
\frac{\partial^{2} E\left(V_{0} ; \bar{D}\right)}{\partial z \partial \eta}=\frac{2 z V_{0}}{(1+z)^{3}}>0
$$


in the high leverage case so that

$$
\frac{\frac{\partial^{2} E\left(V_{0} ; \bar{D}\right)}{\partial z \partial \eta}}{\frac{\partial^{2} E\left(V_{0} ; \underline{D}\right)}{\partial z \partial \eta}}=\frac{\frac{2 z V_{0}}{(1+z)^{3}}}{\frac{2 V_{0}}{(1+z)^{3}}}=z>1 .
$$

As in the case with investment, debt enforcement has a greater effect on risk-shifting incentives when default risk is larger. 


\section{Acknowledgements}

We thank the referee and the editor (Toni Whited) for detailed and constructive feedback on the paper. We also thank Regis Blazy, Asaf Eisdorfer, Florian Heider, Mauricio Larraín, Steven Ongena, Clemens Otto, Andrea Polo, Alexander Wagner, and seminar participants at the Bank of Canada, Bocconi University, Boston College, EPFL, Lancaster University School of Management, Lund University, HEC Lausanne, HEC Montreal, HEC Paris, National University of Singapore, Nova School of Business and Economics, Singapore Management University, Universita Cattolica del Sacro Cuore Milan, the University of Bern, the University of British Columbia, the University of Florida, the University of Hong Kong, the University of Reading, the 2014 WFA Meetings, the 2014 European Summer Symposium on Financial Markets (Gerzensee), the 2014 European Finance Association Meetings, the 2014 Skinance Conference, the 2014 Finance Down Under Conference, the 2014 Darden International Finance Conference, the 2015 FIRS Conference, and the 2015 AFFI conference. Erwan Morellec acknowledges financial support from the Swiss Finance Institute. The views in this paper do not reflect those of the Federal Reserve System or its Board of Governors. 


\section{References}

Acharya, V., Amihud, Y., Litov, L., 2011. Creditor rights and corporate risk-taking. Journal of Financial Economics 102, 105-166.

Acharya, V., Sundaram, R., John, K., 2011. Cross-country variations in capital structures: the role of bankruptcy codes. Journal of Financial Intermediation 20, 25-54.

Alencar, L., Ponticelli, J., 2016. Court enforcement, bank loans and firm investment: Evidence from a bankruptcy reform in Brazil. Quarterly Journal of Economics, Forthcoming.

Andrade, G., Kaplan, S., 1998. How costly is financial (not economic) distress? Evidence from highly leveraged transactions that become distressed. Journal of Finance 53, 1443-1493.

Bartram, S., Brown, G., Stulz, R., 2012. Why are U.S. stocks more volatile? Journal of Finance 67, 1329-1370.

Becker, B., Stromberg, P., 2012. Fiduciary duties and equity-debtholder conflicts. Review of Financial Studies 25, 1931-1969.

Bharath, S., Shumway, T., 2008. Forecasting default with the Merton distance to default model. Review of Financial Studies 21, 1339-1369.

Bris, A., Koskinen, Y., Nilsson, M., 2009. The Euro and corporate valuations. Review of Financial Studies 22, 3171-3209.

Chen, Z., Strebulaev, I., Xing, Y., Zhang, X., 2014. Strategic risk shifting and the idiosyncratic volatility puzzle. Unpublished working paper. Stanford University.

Davydenko, S., Strebulaev, I., 2007. Strategic actions and credit spreads: an empirical investigation. Journal of Finance 62, 2633-2671.

Davydenko, S., Strebulaev, I., Zhao, X., 2012. A market-based study of the cost of default. Review of Financial Studies 25, 3573-3609.

Djankov, S., Hart, O., McLiesh, C., Shleifer, A., 2008. Debt enforcement around the world. Journal of Political Economy 116, 1105-1149.

Djankov, S., McLiesh, C., Shleifer, A., 2007. Private credit in 129 countries. Journal of Financial Economics 84, 299-329.

Eberhart, A., Moore, W., Roenfeldt, P., 1990. Security pricing and deviations from the absolute priority rule in bankruptcy proceedings. Journal of Finance 45, 1457-1469. 
Eisdorfer, A., 2008. Empirical evidence of risk-shifting in financially distressed firms. Journal of Finance 63, 609-637.

Erickson, T., Jiang, C., Whited, T., 2014. Minimum distance estimation of the error-invariables model using linear cumulant equations. Journal of Econometrics 183, 211-221.

Erickson, T., Whited, T., 2000. Measurement errors and the relationship between investment and Q. Journal of Political Economy 108, 1027-1057.

Fan, H., Sundaresan, S., 2000. Debt valuation, renegotiation, and optimal dividend policy. Review of Financial Studies 13, 1057-1099.

Favara, G., Schroth, E., Valta, P., 2012. Strategic default and equity risk across countries. Journal of Finance 67, 2051-2095.

François, P., Morellec, E., 2004. Capital structure and asset prices: some effects of bankruptcy procedures. Journal of Business 77, 387-411.

Franks, J., Torous, W., 1989. An empirical investigation of U.S. firms in reorganization. Journal of Finance 44, 747-769.

Franks, J., Torous, W., 1994. A comparison of financial recontracting in distressed exchanges and Chapter 11 reorganizations. Journal of Financial Economics 35, 349-370.

Garlappi, L., Shu, T., Yan, H., 2008. Default risk, shareholder advantage, and stock returns. Review of Financial Studies 21, 2743-2778.

Garlappi, L., Yan, H., 2011. Financial distress and the cross-section of equity returns. Journal of Finance 66, 789-822.

Gennaioli, N., Rossi, S., 2013. Contractual resolutions of financial distress. Review of Financial Studies 26, 602-634.

Glover, B., 2016. The expected cost of default. Journal of Financial Economics 119, 284-299.

Gormley, T., Matsa, D., 2011. Growing out of trouble: corporate responses to liability risk. Review of Financial Studies 24, 2781-2821.

Gungoraydinoglu, A., Oztekin, O., 2011. Firm- and country-level determinants of corporate leverage: some new international evidence. Journal of Corporate Finance 17, 1457-1474.

Hackbarth, D., Haselman, R., Schoenherr, D., 2015. Financial distress, stock returns, and the 1978 Bankruptcy Reform Act. Review of Financial Studies 28, 1810-1847.

Jensen, M., Meckling, W., 1976. Theory of the firm: managerial behavior, agency costs, and ownership structure. Journal of Financial Economics 3, 305-360. 
John, K., Litov, L., Yeung, B., 2008. Corporate governance and risk-taking. Journal of Finance 63, 1679-1728.

Klee, K., 1979. All you ever wanted to know about cram down under the new bankruptcy code. American Bankruptcy Law Journal 53, 133-171.

Landier, A., Sraer, D., Thesmar, D., 2015. The risk-shifting hypothesis: evidence from subprime originations. Unpublished working paper. Toulouse School of Economics.

Lang, L., Poulsen, A., Stulz, R., 1995. Asset sales, firm performance, and the agency costs of managerial discretion. Journal of Financial Economics 37, 3-37.

La Porta, R., Lopez-de-Silanes, F., Shleifer, A., Vishny, R., 1998. Law and finance. Journal of Political Economy 106, 1113-1155.

La Porta, R., Lopez-de-Silanes, F., Shleifer, A., 2008. The economic consequences of legal origins. Journal of Economic Literature 46, 285-332.

Lemmon, M., Roberts, M., Zender, J., 2008. Back to the beginning: persistence and the cross-section of corporate capital structure. Journal of Finance 63, 1575-1608.

Lerner, J., Schoar, A., 2005. Does legal enforcement affect financial transactions? The contractual channel in private equity. Quarterly Journal of Economics 120, 223-246.

von Lilienfeld-Toal, U., Mookherjee, D., Visaria, S., 2012. The distributive impact of reforms in credit enforcement: evidence from Indian debt recovery tribunals. Econometrica 80, $497-558$.

Merton, R., 1974. On the pricing of corporate debt: the risk structure of interest rates. Journal of Finance 29, 449-470.

Myers, S., 1977. Determinants of corporate borrowing. Journal of Financial Economics 5, $147-175$.

Rodano, G., Serrano Velarde, N., Tarantino, E., 2016. Bankruptcy law and bank financing. Journal of Financial Economics 120, 363-382.

Schlingemann, F., Stulz, R., Walkling, R., 2002. Divestitures and the liquidity of the market for corporate assets. Journal of Financial Economics 64, 117-144.

Vig, V., 2013. Access to collateral and corporate debt structure: evidence from a natural experiment. Journal of Finance 68, 881-927.

Warner, J., 1977. Bankruptcy costs: some evidence. Journal of Finance 32, 337-347. 
Weber, R., 2005. Can the Sauvegarde Reform save French bankruptcy law?: A comparative look at Chapter 11 and French bankruptcy law from an agency cost perspective. Michigan Journal of International Law 27, 257-301.

White, M., 1989. The corporate bankruptcy decision. Journal of Economic Perspectives 3, $129-151$.

Yang, L., 2008. The real determinants of asset sales. Journal of Finance 63, 2231-2262. 

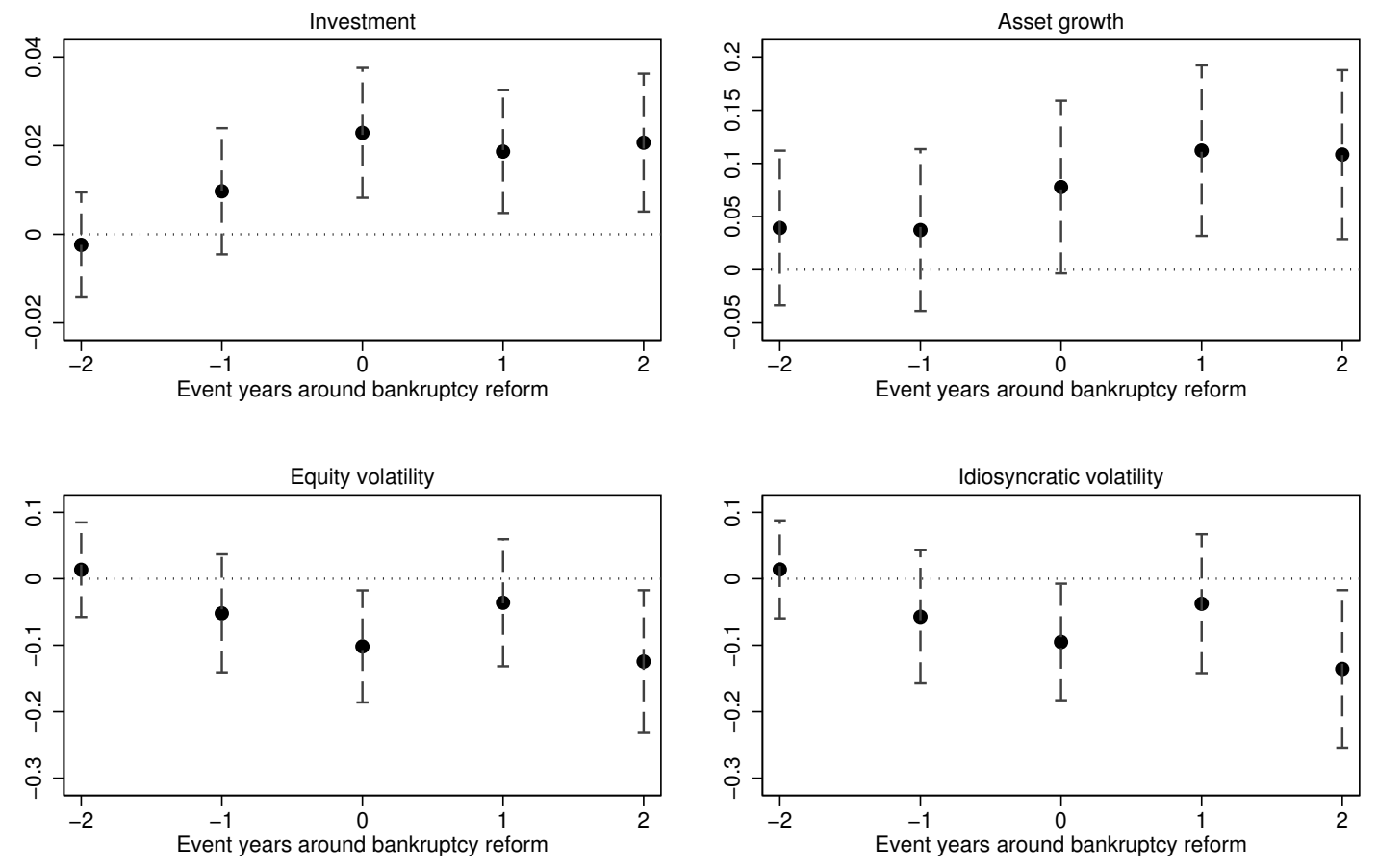

Point estimate $\quad---ー \dashv 95 \%$ Confidence interval

Fig. 1. Bankruptcy reforms in Italy, France, and Brazil. The graph presents the average difference in Investment, Asset growth, Equity volatility, and Idiosyncratic volatility between high and low default probability firms, conditioning on firm and year fixed effects and control variables. The sample period is from 2002 to 2008. The event year 0 corresponds to the bankruptcy reform year in 2005. The point estimates and confidence intervals refer to the coefficients of the interaction terms between the high default probability dummy and annual event-time dummies around the reforms. The point estimates are relative to the year 2002, the year in which firms are sorted in treated (high default probability) and control (low default probability) groups. 

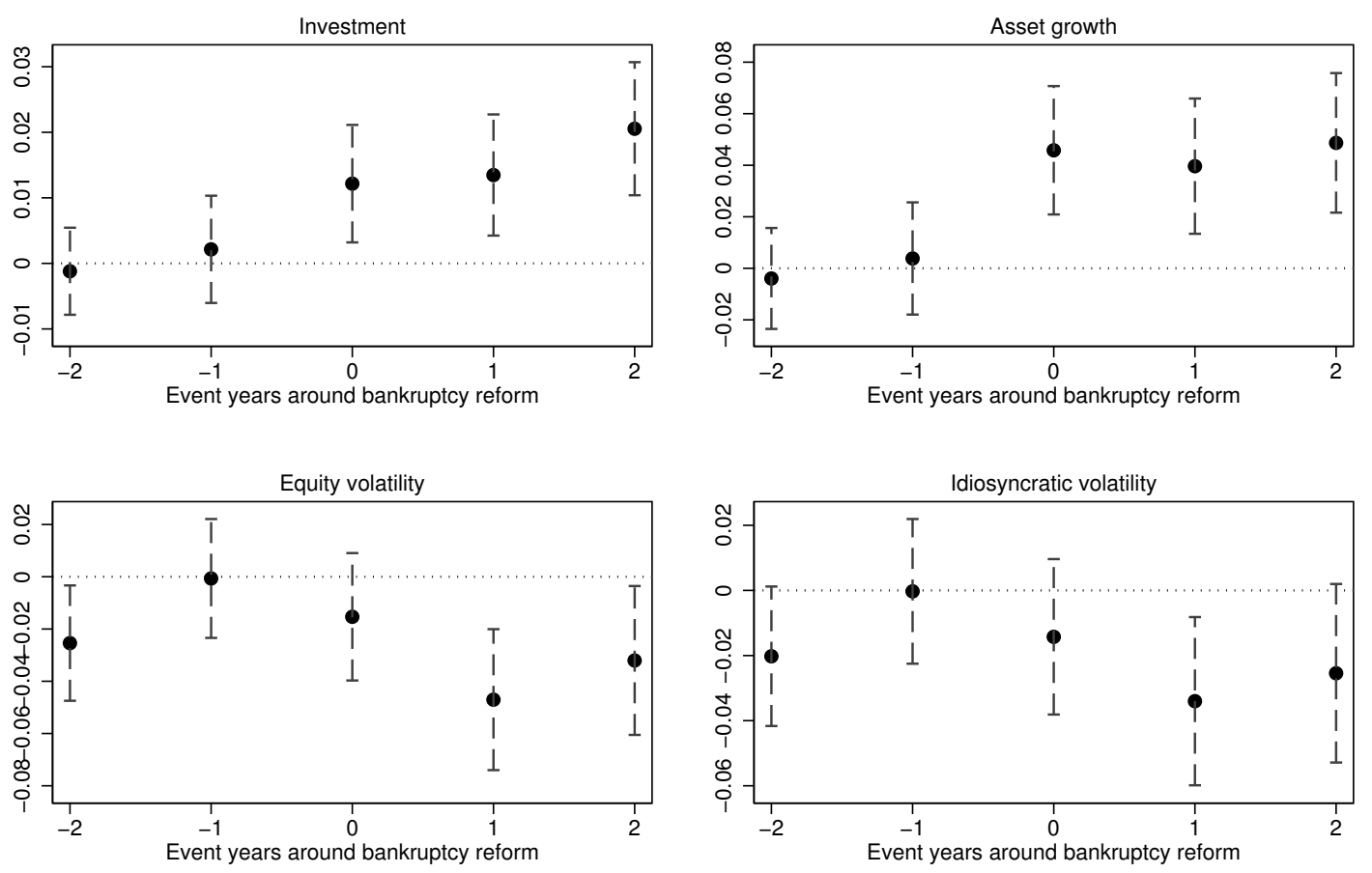

Point estimate $\quad$ - $-ー \dashv 95 \%$ Confidence interval

Fig. 2. U.S. Bankruptcy Reform Act. The graph presents the average difference in Investment, Asset growth, Equity volatility, and Idiosyncratic volatility between high and low default probability firms, conditioning on firm and year fixed effects and control variables. The sample period is from 1976 to 1982 . The event year 0 corresponds to the bankruptcy reform year in 1979. The point estimates and confidence intervals refer to the coefficients of the interaction terms between the high default probability dummy and annual event-time dummies around the reforms. The point estimates are relative to the year 1976, the year in which firms are sorted in treated (high default probability) and control (low default probability) groups. 


\section{Table 1}

Definitions of variables

\begin{tabular}{|c|c|c|}
\hline Variable name & Variable definition & Source \\
\hline Investment & Capital expenditures in year $t /$ Total assets in year $t-1$ & Worldscope \\
\hline Asset growth & Growth in total assets from year $t-1$ to year $t$ & Worldscope \\
\hline Equity vol & $\begin{array}{l}\text { Annualized standard deviation of weekly stock returns } \\
\text { (Friday-to-Friday) in year } t \text {, as in Bartram, Brown, } \\
\text { and Stulz (2012) }\end{array}$ & $\begin{array}{l}\text { Worldscope } \\
\text { Datastream }\end{array}$ \\
\hline Idiosyncratic vol & $\begin{array}{l}\text { Annualized standard deviation of the residuals from the } \\
\text { regression of the firm's weekly stock returns in year } t \\
\text { on the world market index (lag, lead, and contemporaneous) }\end{array}$ & $\begin{array}{l}\text { Worldscope } \\
\text { Datastream }\end{array}$ \\
\hline EBITDA-to-assets vol & $\begin{array}{l}\text { Standard deviation of the ratio of EBITDA to assets between } \\
\text { the years } t-7 \text { and } t \text {, as in John, Litov, and Yeung (2008) }\end{array}$ & Worldscope \\
\hline Default probability $(D P)$ & $\begin{array}{l}\text { Default probability estimate, using Bharath and } \\
\text { Shumway's (2008) approximation of the Merton } \\
\text { Distance-to-Default (DD) model }\end{array}$ & $\begin{array}{l}\text { Worldscope } \\
\text { Datastream }\end{array}$ \\
\hline Asset vol & $\begin{array}{l}\text { Average of equity and debt yearly volatilities (\% per year) } \\
\text { from weekly stock prices, weighted by debt face values } \\
\text { and market equity values, as in Bharath and Shumway (2008) }\end{array}$ & $\begin{array}{l}\text { Worldscope } \\
\text { Datastream }\end{array}$ \\
\hline Debt enforcement ( $\eta)$ & $\begin{array}{l}\text { Index of debt enforcement in default, constructed using the } \\
\text { survey data in Djankov, Hart, McLiesh, and Shleifer (2008) }\end{array}$ & $\begin{array}{l}\text { Djankov } \\
\text { et al. (2008) }\end{array}$ \\
\hline Leverage & Total debt / Total assets & Worldscope \\
\hline Long-term debt & Long-term debt / Total debt & Capital IQ \\
\hline Market-to-book ratio & (Total assets + market cap - book equity) / Total assets & Worldscope \\
\hline Cash flow-to-assets & (Net income + Depreciation \& amortization $) /$ Total assets & Worldscope \\
\hline EBITDA-to-assets & Ratio of EBITDA to total assets & Worldscope \\
\hline $\log ($ Total assets) & Logarithm of total assets & Worldscope \\
\hline $\log (G D P$ per capita $)$ & Logarithm of gross national income per capita & World Bank \\
\hline GDP growth & Annual gross domestic product growth & World Bank \\
\hline Stockmarket cap to GDP & $\begin{array}{l}\text { Ratio of the country's total stock market capitalization to } \\
\text { the total gross national income }\end{array}$ & World Bank \\
\hline Creditor rights & $\begin{array}{l}\text { La Porta et al.'s (1998) country-specific index of creditors' } \\
\text { rights; ranges from } 0 \text { to } 4\end{array}$ & $\begin{array}{l}\text { La Porta } \\
\text { et al. (1998) }\end{array}$ \\
\hline
\end{tabular}




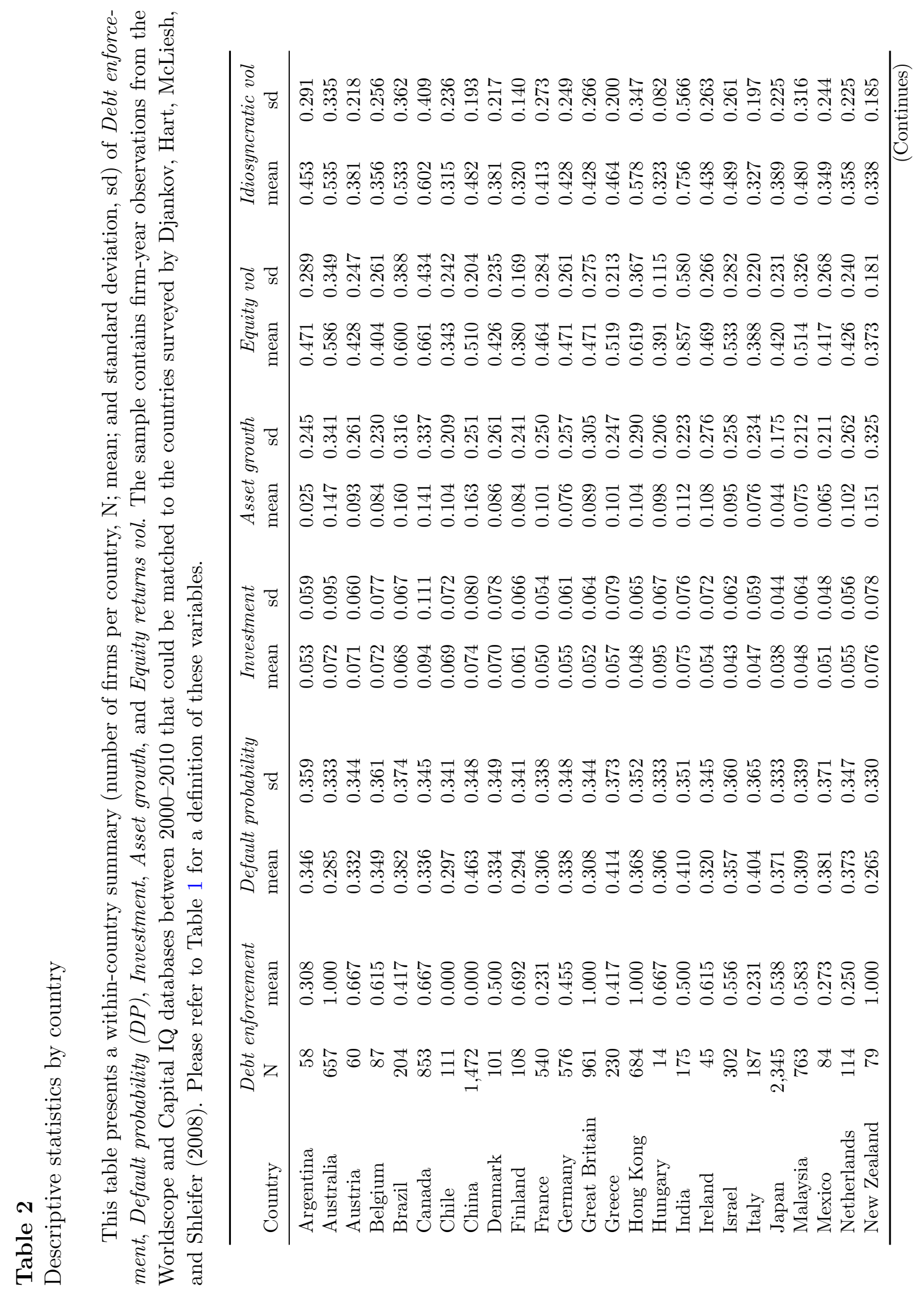




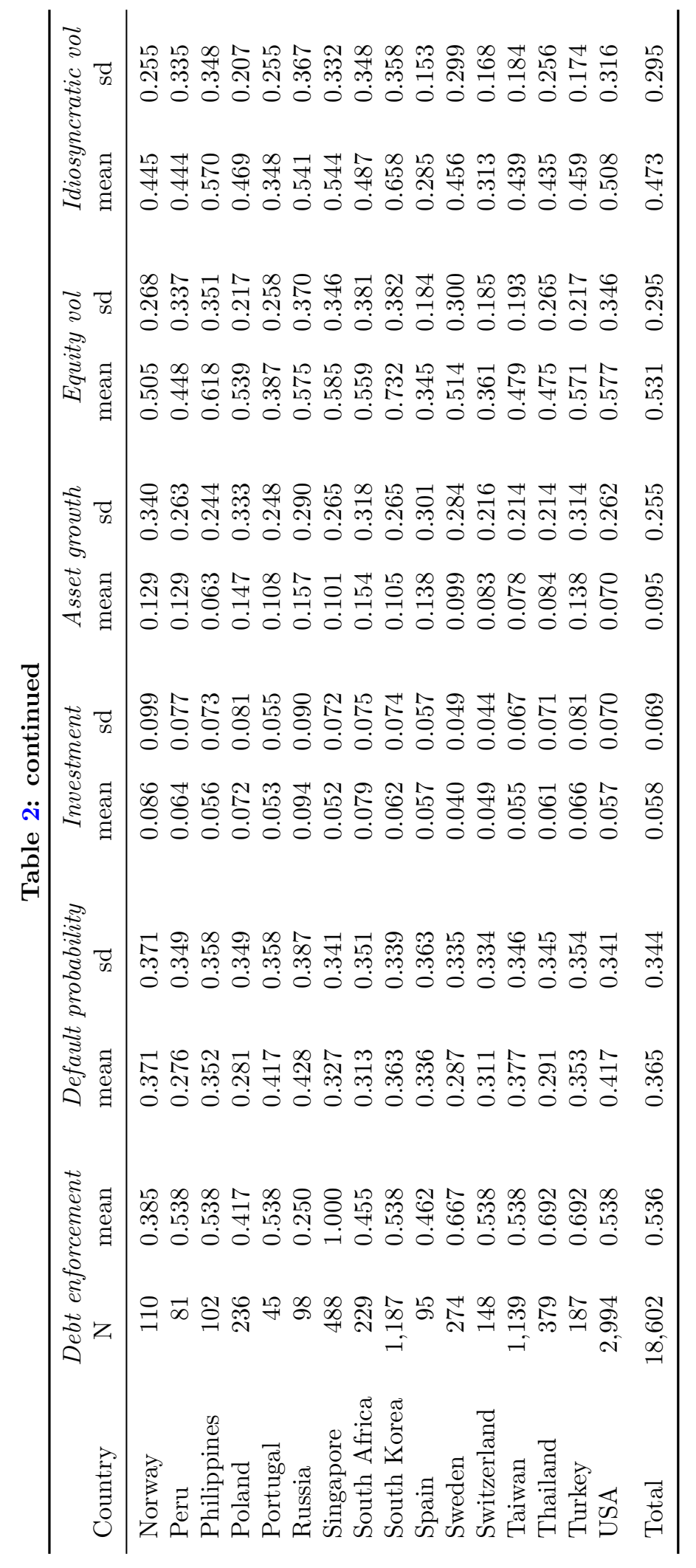




\section{Table 3}

Firm characteristics

This table presents descriptive statistics (number of firm-year observations, N; mean; standard deviation, decomposed into between-firm, $\mathrm{sd}_{b}$, and within-firm, $\mathrm{sd}_{w}$, variation; and the three quartiles: p25, p50, and p75) of the variables used in the analysis. The sample contains firm-year observations from the Worldscope and Capital IQ databases between 2000-2010 that could be matched to the countries surveyed by Djankov, Hart, McLiesh, and Shleifer (2008). Please refer to Table 1 for a definition of these variables.

\begin{tabular}{|c|c|c|c|c|c|c|c|c|}
\hline & \multicolumn{7}{|c|}{ Standard deviation } & \multirow[b]{2}{*}{$\mathrm{p} 75$} \\
\hline & $\mathrm{N}$ & Mean & Total & $\operatorname{sd}_{b}$ & $\mathrm{sd}_{w}$ & $\mathrm{p} 25$ & $\mathrm{p} 50$ & \\
\hline Investment & 113,598 & 0.056 & 0.070 & 0.061 & 0.046 & 0.014 & 0.034 & 0.070 \\
\hline Asset growth & 114,559 & 0.092 & 0.257 & 0.181 & 0.221 & -0.047 & 0.061 & 0.184 \\
\hline Equity vol & 113,950 & 0.518 & 0.307 & 0.288 & 0.204 & 0.316 & 0.441 & 0.625 \\
\hline Idiosyncratic vol & 112,948 & 0.471 & 0.290 & 0.276 & 0.190 & 0.282 & 0.397 & 0.568 \\
\hline EBITDA-to-assets vol & 93,671 & 0.063 & 0.060 & 0.066 & 0.025 & 0.025 & 0.043 & 0.077 \\
\hline Default probability & 112,337 & 0.339 & 0.345 & 0.211 & 0.300 & 0.004 & 0.217 & 0.658 \\
\hline Asset vol & 113,754 & 0.404 & 0.239 & 0.232 & 0.155 & 0.249 & 0.341 & 0.484 \\
\hline Leverage & 114,559 & 0.257 & 0.180 & 0.170 & 0.088 & 0.111 & 0.239 & 0.371 \\
\hline Long-term debt & 86,683 & 0.561 & 0.315 & 0.281 & 0.174 & 0.294 & 0.586 & 0.846 \\
\hline Market-to-book ratio & 114,557 & 1.430 & 1.005 & 0.979 & 0.598 & 0.904 & 1.136 & 1.580 \\
\hline Cash flow-to-assets ratio & 111,517 & 0.068 & 0.118 & 0.121 & 0.075 & 0.028 & 0.071 & 0.123 \\
\hline EBITDA-to-assets & 112,353 & 0.085 & 0.130 & 0.136 & 0.082 & 0.045 & 0.094 & 0.147 \\
\hline $\log ($ Total assets $)$ & 114,559 & 5.464 & 1.809 & 1.792 & 0.377 & 4.215 & 5.323 & 6.599 \\
\hline $\log (G D P$ per capita $)$ & 114,062 & 9.812 & 1.093 & 1.061 & 0.225 & 9.033 & 10.380 & 10.583 \\
\hline GDP growth & 114,491 & 0.035 & 0.041 & 0.035 & 0.025 & 0.014 & 0.029 & 0.052 \\
\hline Stockmarket cap to GDP & 107,848 & 1.090 & 0.820 & 0.771 & 0.298 & 0.663 & 0.995 & 1.296 \\
\hline Creditor rights & 114,559 & 2.212 & 1.106 & 1.109 & 0.106 & 1.000 & 2.000 & 3.000 \\
\hline
\end{tabular}




\section{Table 4}

Debt enforcement and capital investment

This table presents industry and country fixed effects (ICFE), firm fixed effects (FFE), OLS, and fifth-order linear cumulant (LC5) estimates of investment regressions. The sample contains firmyear observations from the Worldscope and Capital IQ databases between 2000-2010 that could be matched to the countries surveyed by Djankov, Hart, McLiesh, and Shleifer (2008). The dependent variable is yearly Investment. All specifications include year fixed effects. The coefficient on Default probability reports the conditional correlation between Investment and Default probability evaluated at the sample mean of Debt enforcement. Standard errors (in parentheses under each estimate) are clustered by country. The $\rho^{2}$ statistic is the coefficient of determination for the LC5 estimator, excluding the variation determined by country and industry fixed effects. Estimates followed by the symbols $^{* * *},{ }^{* *}$, or $^{*}$ are statistically significant at the $1 \%, 5 \%$, or $10 \%$ levels, respectively. Please refer to Table 1 for a definition of all the variables.

\begin{tabular}{|c|c|c|c|c|}
\hline & (1) & $(2)$ & $(3)$ & $(4)$ \\
\hline Specification & ICFE & FFE & OLS & LC5 \\
\hline Default probability (DP) & $\begin{array}{c}-0.003^{* *} \\
(0.002)\end{array}$ & $\begin{array}{l}-0.007^{* * *} \\
(0.002)\end{array}$ & $\begin{array}{c}0.000 \\
(0.002)\end{array}$ & $\begin{array}{c}-0.005^{* * *} \\
(0.001)\end{array}$ \\
\hline$D P \times$ Debt enforcement & $\begin{array}{c}-0.008^{* *} \\
(0.004)\end{array}$ & $\begin{array}{c}-0.008^{* *} \\
(0.004)\end{array}$ & $\begin{array}{c}-0.011^{* *} \\
(0.005)\end{array}$ & $\begin{array}{c}-0.010^{* * *} \\
(0.003)\end{array}$ \\
\hline Debt enforcement $(\eta)$ & & & $\begin{array}{c}0.005 \\
(0.006)\end{array}$ & \\
\hline Market-to-book ratio & $\begin{array}{l}0.007^{* * *} \\
(0.001)\end{array}$ & $\begin{array}{l}0.008^{* * *} \\
(0.001)\end{array}$ & $\begin{array}{l}0.007^{* * *} \\
(0.001)\end{array}$ & $\begin{array}{l}0.004^{* * *} \\
(0.001)\end{array}$ \\
\hline Cash flow-to-assets & $\begin{array}{l}0.172^{* * *} \\
(0.021)\end{array}$ & $\begin{array}{l}0.094^{* * *} \\
(0.015)\end{array}$ & $\begin{array}{l}0.202^{* * *} \\
(0.022)\end{array}$ & $\begin{array}{c}0.006 \\
(0.011)\end{array}$ \\
\hline EBITDA-to-assets & $\begin{array}{l}-0.045^{* * *} \\
(0.009)\end{array}$ & $\begin{array}{r}-0.016^{*} \\
(0.010)\end{array}$ & $\begin{array}{l}-0.049^{* * *} \\
(0.014)\end{array}$ & $\begin{array}{l}0.111^{* * *} \\
(0.010)\end{array}$ \\
\hline $\log ($ Total assets $)$ & $\begin{array}{l}-0.001^{* * *} \\
(0.000)\end{array}$ & $\begin{array}{l}-0.019^{* * *} \\
(0.002)\end{array}$ & $\begin{array}{c}0.000 \\
(0.000)\end{array}$ & $\begin{array}{c}0.001 \\
(0.000)\end{array}$ \\
\hline GDP growth & $\begin{array}{c}0.044 \\
(0.028)\end{array}$ & $\begin{array}{c}0.024 \\
(0.033)\end{array}$ & $\begin{array}{l}0.121^{* * *} \\
(0.041)\end{array}$ & $\begin{array}{l}0.050^{* * *} \\
(0.015)\end{array}$ \\
\hline $\log (G D P$ per capita) & $\begin{array}{l}-0.000 \\
(0.003)\end{array}$ & $\begin{array}{c}0.006 \\
(0.005)\end{array}$ & $\begin{array}{c}-0.002 \\
(0.002)\end{array}$ & $\begin{array}{c}0.002 \\
(0.374)\end{array}$ \\
\hline Stockmarket cap to GDP & $\begin{array}{c}0.003 \\
(0.002)\end{array}$ & $\begin{array}{c}0.002 \\
(0.002)\end{array}$ & $\begin{array}{c}-0.002 \\
(0.001)\end{array}$ & $\begin{array}{l}0.003^{* * *} \\
(0.001)\end{array}$ \\
\hline $\begin{array}{l}\text { Observations } \\
R^{2}\end{array}$ & $\begin{array}{l}102,239 \\
0.25\end{array}$ & $\begin{array}{c}102,239 \\
0.53\end{array}$ & $\begin{array}{c}102,239 \\
0.10\end{array}$ & 102,239 \\
\hline$\rho^{2}$ & & & & 0.06 \\
\hline \multicolumn{5}{|c|}{ Economic significance : $\Delta E(y) \equiv E(y \mid \eta=0,)-.E(y \mid \eta=1,)}$. \\
\hline $\begin{array}{l}\Delta E(\text { Investment }) \\
\text { Standard error }\end{array}$ & $\begin{array}{l}0.007^{* *} \\
(0.003)\end{array}$ & $\begin{array}{l}0.007^{* *} \\
(0.003)\end{array}$ & $\begin{array}{c}0.004 \\
(0.005)\end{array}$ & $\begin{array}{l}0.009^{* * *} \\
(0.002)\end{array}$ \\
\hline$\frac{\Delta E(\text { Investment })}{\text { mean Investment }}$ & 0.143 & 0.144 & 0.085 & 0.174 \\
\hline
\end{tabular}




\section{Table 5}

Debt enforcement and asset growth

This table presents industry and country fixed effects (ICFE), firm fixed effects (FFE), OLS, and fifth-order linear cumulant (LC5) estimates of asset growth regressions. The sample contains firmyear observations from the Worldscope and Capital IQ databases between 2000-2010 that could be matched to the countries surveyed by Djankov, Hart, McLiesh, and Shleifer (2008). The dependent variable is Asset growth. All specifications include year fixed effects. The coefficient on Default probability reports the conditional correlation between Asset growth and Default probability evaluated at the sample mean of Debt enforcement. Standard errors (in parentheses under each estimate) are clustered by country. The $\rho^{2}$ statistic is the coefficient of determination for the LC5 estimator, excluding the variation determined by country and industry fixed effects. Estimates followed by the symbols $^{* * *},{ }^{* *}$, or ${ }^{*}$ are statistically significant at the $1 \%, 5 \%$, or $10 \%$ levels, respectively. Please refer to Table 1 for a definition of all the variables.

\begin{tabular}{|c|c|c|c|c|}
\hline & (1) & $(2)$ & $(3)$ & $(4)$ \\
\hline Specification & ICFE & FFE & OLS & LC5 \\
\hline Default probability (DP) & $\begin{array}{c}-0.036^{* *} \\
(0.014)\end{array}$ & $\begin{array}{r}-0.013 \\
(0.014)\end{array}$ & $\begin{array}{c}-0.042^{* *} \\
(0.017)\end{array}$ & $\begin{array}{l}0.007^{* *} \\
(0.003)\end{array}$ \\
\hline$D P \times$ Debt enforcement & $\begin{array}{c}-0.057^{* *} \\
(0.026)\end{array}$ & $\begin{array}{c}-0.054^{* *} \\
(0.028)\end{array}$ & $\begin{array}{r}-0.051^{*} \\
(0.027)\end{array}$ & $\begin{array}{c}-0.064^{* * *} \\
(0.011)\end{array}$ \\
\hline Debt enforcement $(\eta)$ & & & $\begin{array}{c}0.017 \\
(0.019)\end{array}$ & \\
\hline Market-to-book ratio & $\begin{array}{l}0.043^{* * *} \\
(0.005)\end{array}$ & $\begin{array}{l}0.048^{* * *} \\
(0.009)\end{array}$ & $\begin{array}{l}0.041^{* * *} \\
(0.004)\end{array}$ & $\begin{array}{l}0.152^{* * *} \\
(0.004)\end{array}$ \\
\hline Cash flow-to-assets & $\begin{array}{l}0.393^{* * *} \\
(0.044)\end{array}$ & $\begin{array}{l}0.240^{* * *} \\
(0.039)\end{array}$ & $\begin{array}{l}0.409^{* * *} \\
(0.042)\end{array}$ & $\begin{array}{l}0.378^{* * *} \\
(0.072)\end{array}$ \\
\hline EBITDA-to-assets & $\begin{array}{r}-0.002 \\
(0.025)\end{array}$ & $\begin{array}{l}0.114^{* * *} \\
(0.029)\end{array}$ & $\begin{array}{r}-0.011 \\
(0.032)\end{array}$ & $\begin{array}{r}-0.086 \\
(0.061)\end{array}$ \\
\hline $\log ($ Total assets $)$ & $\begin{array}{c}-0.006^{* * *} \\
(0.001)\end{array}$ & $\begin{array}{c}-0.217^{* * *} \\
(0.016)\end{array}$ & $\begin{array}{c}-0.004^{* *} \\
(0.002)\end{array}$ & $\begin{array}{r}-0.001 \\
(0.001)\end{array}$ \\
\hline GDP growth & $\begin{array}{l}0.782^{* * *} \\
(0.262)\end{array}$ & $\begin{array}{l}0.575^{* *} \\
(0.244)\end{array}$ & $\begin{array}{l}0.786^{* * *} \\
(0.145)\end{array}$ & $\begin{array}{l}0.963^{* * *} \\
(0.060)\end{array}$ \\
\hline $\log (G D P$ per capita $)$ & $\begin{array}{l}0.070^{* * *} \\
(0.017)\end{array}$ & $\begin{array}{l}0.187^{* * *} \\
(0.040)\end{array}$ & $\begin{array}{c}0.003 \\
(0.006)\end{array}$ & $\begin{array}{l}0.036^{* * *} \\
(0.007)\end{array}$ \\
\hline Stockmarket cap to GDP & $\begin{array}{l}0.035^{* * *} \\
(0.010)\end{array}$ & $\begin{array}{c}0.031^{* *} \\
(0.013)\end{array}$ & $\begin{array}{c}0.004 \\
(0.004)\end{array}$ & $\begin{array}{l}0.025^{\text {*** }} \\
(0.004)\end{array}$ \\
\hline $\begin{array}{l}\text { Observations } \\
R^{2}\end{array}$ & $\begin{array}{l}103,028 \\
0.15\end{array}$ & $\begin{array}{c}103,028 \\
0.41\end{array}$ & $\begin{array}{l}103,028 \\
0.13\end{array}$ & 103,028 \\
\hline$\rho^{2}$ & & & & 0.14 \\
\hline \multicolumn{5}{|c|}{ Economic significance : $\Delta E(y) \equiv E(y \mid \eta=0,)-.E(y \mid \eta=1,)}$. \\
\hline $\begin{array}{l}\Delta E(\text { Asset growth }) \\
\text { Standard error }\end{array}$ & $\begin{array}{l}0.049^{* *} \\
(0.022)\end{array}$ & $\begin{array}{r}0.046^{*} \\
(0.024)\end{array}$ & $\begin{array}{c}0.027 \\
(0.019)\end{array}$ & $\begin{array}{l}0.055^{* * *} \\
(0.010)\end{array}$ \\
\hline$\frac{\Delta E(\text { Asset growth })}{\text { mean Asset growth }}$ & 0.787 & 0.754 & 0.433 & 0.888 \\
\hline
\end{tabular}




\section{Table 6}

Debt enforcement and risk

This table presents industry and country fixed effects (ICFE), firm fixed effects (FFE), and OLS estimates of risk regressions. The sample contains firm-year observations from the Worldscope and Capital IQ databases between 2000-2010 that could be matched to the countries surveyed by Djankov, Hart, McLiesh, and Shleifer (2008). The dependent variable is Equity vol in columns 1 to 3 of Panel A, Idiosyncratic vol in columns 4 to 6 of Panel A, total implied Asset vol in columns 1 to 3 of Panel B, and EBITDA-to-assets vol in columns 4 to 6 of Panel B. All specifications include year fixed effects. The coefficient on Default probability reports the conditional correlation between the dependent variable and Default probability evaluated at the sample mean of Debt enforcement. Standard errors (in parentheses under each estimate) are clustered by country. Estimates followed by the symbols ${ }^{* * *},{ }^{* *}$, or ${ }^{*}$ are statistically significant at the $1 \%, 5 \%$, or $10 \%$ levels, respectively. Please refer to Table 1 for a definition of all the variables.

\section{Panel $A$}

Dependent variable:

Equity vol

Idiosyncratic vol

(1)

(2)

(3)

(4)

(5)

(6)

\begin{tabular}{lcccccc} 
Specification & ICFE & FFE & OLS & ICFE & FFE & OLS \\
\hline Default probability (DP) & $0.219^{* * *}$ & $0.145^{* * *}$ & $0.229^{* * *}$ & $0.207^{* * *}$ & $0.136^{* * *}$ & $0.215^{* * *}$ \\
& $(0.019)$ & $(0.021)$ & $(0.024)$ & $(0.018)$ & $(0.018)$ & $(0.023)$ \\
DP $\times$ Debt enforcement & $0.207^{* * *}$ & $0.197^{* * *}$ & $0.246^{* * *}$ & $0.210^{* * *}$ & $0.201^{* * *}$ & $0.245^{* * *}$ \\
& $(0.068)$ & $(0.068)$ & $(0.081)$ & $(0.067)$ & $(0.068)$ & $(0.083)$ \\
Debt enforcement & & & -0.046 & & & -0.059 \\
& & & $(0.056)$ & & & $(0.051)$ \\
Market-to-book ratio & $0.012^{* *}$ & 0.002 & $0.018^{*}$ & $0.009^{*}$ & -0.003 & $0.013^{*}$ \\
& $(0.005)$ & $(0.006)$ & $(0.009)$ & $(0.005)$ & $(0.005)$ & $(0.007)$ \\
Cash flow-to-assets & $-0.185^{* * *}$ & -0.078 & $-0.194^{* * *}$ & $-0.228^{* * *}$ & $-0.094^{* *}$ & $-0.235^{* * *}$ \\
& $(0.041)$ & $(0.047)$ & $(0.051)$ & $(0.039)$ & $(0.042)$ & $(0.049)$ \\
EBITDA-to-assets & $-0.362^{* * *}$ & $-0.225^{* * *}$ & $-0.341^{* * *}$ & $-0.303^{* * *}$ & $-0.195^{* * *}$ & $-0.291^{* * *}$ \\
& $(0.038)$ & $(0.059)$ & $(0.050)$ & $(0.032)$ & $(0.052)$ & $(0.045)$ \\
log Total assets) & $-0.052^{* * *}$ & $-0.044^{* * *}$ & $-0.050^{* * *}$ & $-0.057^{* * *}$ & $-0.056^{* * *}$ & $-0.056^{* * *}$ \\
GDP growth & $(0.005)$ & $(0.011)$ & $(0.004)$ & $(0.005)$ & $(0.010)$ & $(0.004)$ \\
& 0.09 & 0.006 & 0.716 & 0.036 & -0.051 & $0.729^{*}$ \\
log(GDP per capital) & $(0.237)$ & $(0.281)$ & $(0.471)$ & $(0.245)$ & $(0.280)$ & $(0.388)$ \\
Stockmarket cap to GDP & $0.089^{* * *}$ & 0.056 & 0.003 & $0.091^{* * *}$ & $0.066^{* *}$ & -0.001 \\
& $(0.032)$ & $(0.037)$ & $(0.023)$ & $(0.028)$ & $(0.032)$ & $(0.020)$ \\
Observations & $0.055^{* *}$ & $0.044^{*}$ & 0.020 & $0.062^{* * *}$ & $0.049^{*}$ & $0.022^{*}$ \\
$R^{2}$ & $(0.021)$ & $(0.024)$ & $(0.014)$ & $(0.022)$ & $(0.025)$ & $(0.012)$ \\
\hline & 108,700 & 108,700 & 108,700 & 105,111 & 105,111 & 105,111 \\
& 0.39 & 0.65 & 0.29 & 0.39 & 0.65 & 0.30 \\
\hline
\end{tabular}

Economic significance : $\Delta E(y) \equiv E(y \mid \eta=0,)-.E(y \mid \eta=1,$.

\begin{tabular}{lcccccc}
\hline$\Delta E($ Dependent variable $)$ & $-0.177^{* * *}$ & $-0.168^{* * *}$ & $-0.209^{* * *}$ & $-0.179^{* * *}$ & $-0.171^{* * *}$ & $-0.209^{* * *}$ \\
Standard error & $(0.057)$ & $(0.058)$ & $(0.068)$ & $(0.056)$ & $(0.057)$ & $(0.070)$ \\
$\Delta E($ Dependent variable $)$ & -0.372 & -0.353 & -0.440 & -0.399 & -0.381 & -0.466 \\
\hline mean Dependent variable & & & & & \\
\hline
\end{tabular}


Table 6: continued

\begin{tabular}{|c|c|c|c|c|c|c|}
\hline \multirow[t]{2}{*}{ Dependent variable: } & \multicolumn{3}{|c|}{ Asset vol } & \multicolumn{3}{|c|}{ EBITDA-to-assets vol } \\
\hline & $(1)$ & $(2)$ & $(3)$ & $(4)$ & $(5)$ & (6) \\
\hline Specification & ICFE & FFE & OLS & ICFE & FFE & OLS \\
\hline Default probability (DP) & $\begin{array}{l}0.059^{* * *} \\
(0.012)\end{array}$ & $\begin{array}{l}0.060^{* * *} \\
(0.013)\end{array}$ & $\begin{array}{l}0.066^{* * *} \\
(0.015)\end{array}$ & $\begin{array}{l}0.014^{* * *} \\
(0.002)\end{array}$ & $\begin{array}{c}0.003^{* *} \\
(0.001)\end{array}$ & $\begin{array}{c}0.016^{* *} \\
(0.002)\end{array}$ \\
\hline$D P \times$ Debt enforcement & $\begin{array}{c}0.095^{* *} \\
(0.038)\end{array}$ & $\begin{array}{l}0.120^{* * *} \\
(0.042)\end{array}$ & $\begin{array}{l}0.111^{* *} \\
(0.044)\end{array}$ & $\begin{array}{c}0.006 \\
(0.004)\end{array}$ & $\begin{array}{c}0.005^{*} \\
(0.003)\end{array}$ & $\begin{array}{c}0.011^{* *} \\
(0.004)\end{array}$ \\
\hline Debt enforcement $(\eta)$ & & & $\begin{array}{c}-0.038 \\
(0.044)\end{array}$ & & & $\begin{array}{c}0.021^{* *} \\
(0.010)\end{array}$ \\
\hline Market-to-book ratio & $\begin{array}{l}0.028^{* * *} \\
(0.004)\end{array}$ & $\begin{array}{c}0.009^{*} \\
(0.005)\end{array}$ & $\begin{array}{l}0.040^{* * *} \\
(0.007)\end{array}$ & $\begin{array}{l}0.013^{* * *} \\
(0.001)\end{array}$ & $\begin{array}{l}0.002^{* * *} \\
(0.000)\end{array}$ & $\begin{array}{l}0.017^{* * *} \\
(0.002)\end{array}$ \\
\hline Cash flow-to-assets & $\begin{array}{c}0.043 \\
(0.031)\end{array}$ & $\begin{array}{c}0.027 \\
(0.035)\end{array}$ & $\begin{array}{c}0.042 \\
(0.030)\end{array}$ & $\begin{array}{l}0.047^{* * *} \\
(0.013)\end{array}$ & $\begin{array}{l}0.021^{* * *} \\
(0.007)\end{array}$ & $\begin{array}{c}0.047^{* *} \\
(0.021)\end{array}$ \\
\hline EBITDA-to-assets & $\begin{array}{c}-0.391^{* * *} \\
(0.037)\end{array}$ & $\begin{array}{c}-0.166^{* * *} \\
(0.044)\end{array}$ & $\begin{array}{c}-0.389^{* * *} \\
(0.045)\end{array}$ & $\begin{array}{c}-0.182^{* * *} \\
(0.013)\end{array}$ & $\begin{array}{c}-0.055^{* * *} \\
(0.010)\end{array}$ & $\begin{array}{c}-0.166^{* * *} \\
(0.024)\end{array}$ \\
\hline $\log ($ Total assets $)$ & $\begin{array}{c}-0.042^{* * *} \\
(0.004)\end{array}$ & $\begin{array}{c}-0.068^{* * *} \\
(0.009)\end{array}$ & $\begin{array}{c}-0.041^{* * *} \\
(0.003)\end{array}$ & $\begin{array}{c}-0.010^{* * *} \\
(0.001)\end{array}$ & $\begin{array}{c}-0.009^{* * *} \\
(0.001)\end{array}$ & $\begin{array}{c}-0.010^{* * *} \\
(0.001)\end{array}$ \\
\hline GDP growth & $\begin{array}{c}0.300 \\
(0.200)\end{array}$ & $\begin{array}{c}0.191 \\
(0.217)\end{array}$ & $\begin{array}{c}0.797^{* *} \\
(0.341)\end{array}$ & $\begin{array}{c}0.024 \\
(0.034)\end{array}$ & $\begin{array}{c}0.024 \\
(0.024)\end{array}$ & $\begin{array}{r}-0.051 \\
(0.117)\end{array}$ \\
\hline $\log (G D P$ per capital $)$ & $\begin{array}{c}0.049^{* *} \\
(0.022)\end{array}$ & $\begin{array}{c}0.063^{* *} \\
(0.026)\end{array}$ & $\begin{array}{c}0.011 \\
(0.020)\end{array}$ & $\begin{array}{c}0.001 \\
(0.003)\end{array}$ & $\begin{array}{c}0.003 \\
(0.003)\end{array}$ & $\begin{array}{c}0.001 \\
(0.004)\end{array}$ \\
\hline Stockmarket cap to GDP & $\begin{array}{c}0.054^{* *} \\
(0.021)\end{array}$ & $\begin{array}{c}0.050^{* *} \\
(0.023)\end{array}$ & $\begin{array}{c}0.023^{* *} \\
(0.010)\end{array}$ & $\begin{array}{r}-0.002^{*} \\
(0.001)\end{array}$ & $\begin{array}{c}-0.001 \\
(0.001)\end{array}$ & $\begin{array}{c}0.002 \\
(0.002)\end{array}$ \\
\hline Observations & 108,700 & 108,700 & 108,700 & 79,830 & 79,830 & 79,830 \\
\hline$R^{2}$ & 0.36 & 0.64 & 0.26 & 0.33 & 0.84 & 0.21 \\
\hline
\end{tabular}

Economic significance : $\Delta E(y) \equiv E(y \mid \eta=0,)-.E(y \mid \eta=1,$.

\begin{tabular}{lcccccc}
\hline$\Delta E($ Dependent variable $)$ & $-0.081^{* *}$ & $-0.102^{* * *}$ & $-0.094^{* *}$ & -0.005 & $-0.004^{*}$ & $-0.009^{* * *}$ \\
Standard error & $(0.032)$ & $(0.035)$ & $(0.037)$ & $(0.003)$ & $(0.002)$ & $(0.003)$ \\
$\frac{\Delta E(\text { Dependent variable })}{\text { mean Dependent variable }}$ & -0.212 & -0.267 & -0.246 & -0.099 & -0.077 & -0.183 \\
\hline
\end{tabular}



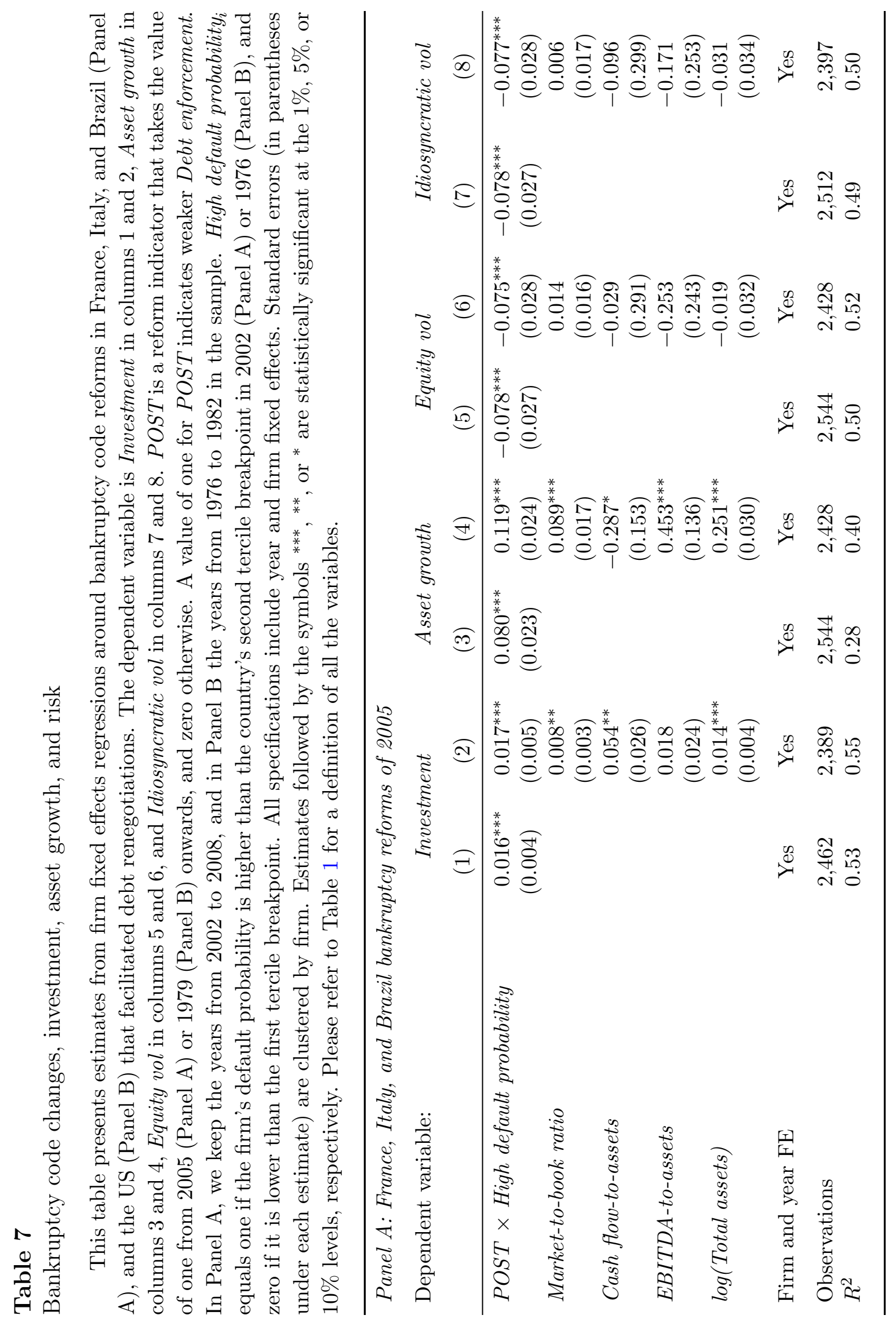


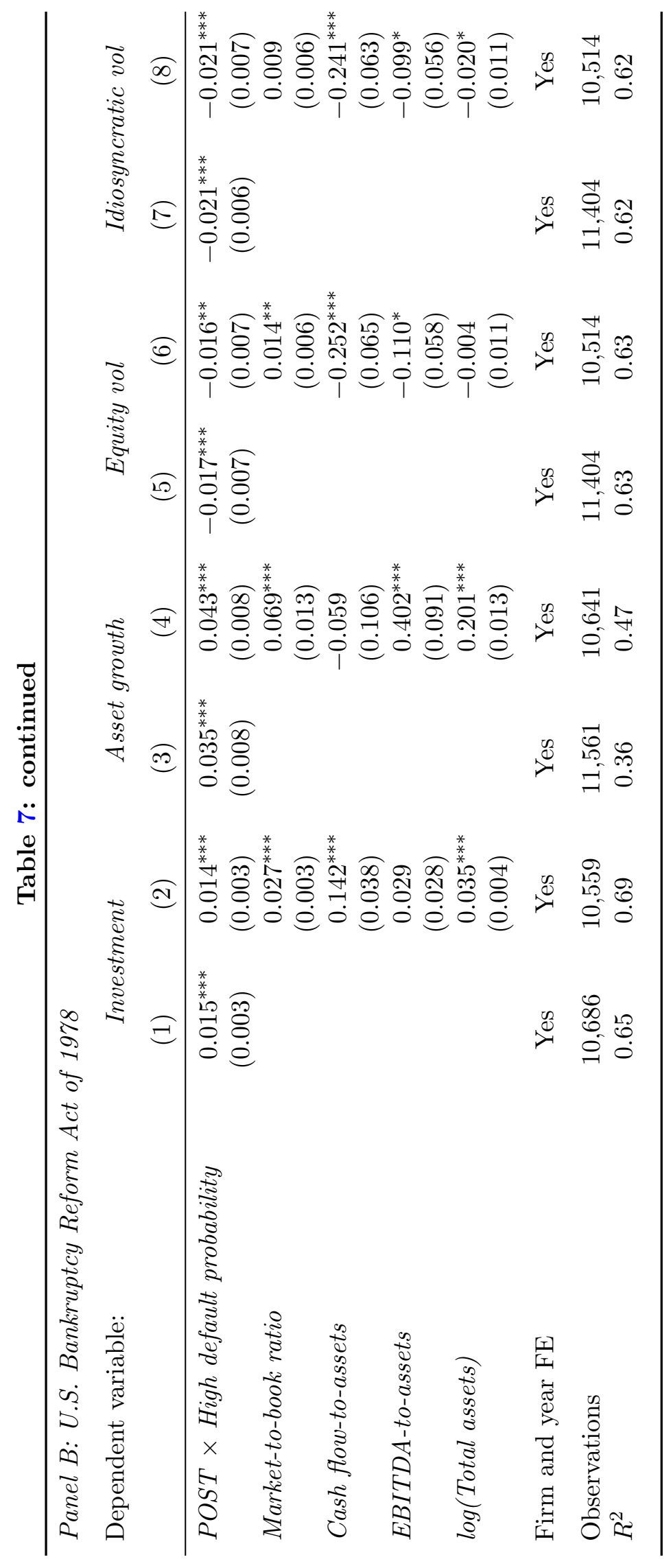




\section{Table 8}

Robustness analysis: Creditor rights, investment, and risk

The table presents industry and country fixed effects estimates of investment, asset growth, and risk regressions. The sample contains firm-year observations from the Worldscope and Capital IQ databases between 2000-2010 that could be matched to the countries surveyed by Djankov, Hart, McLiesh, and Shleifer (2008). All columns include Market-to-book ratio, Cash flow-to-capital, EBITDA-to-assets, $\log$ (Total assets), GDP growth, $\log (G D P$ per capita), and Stockmarket cap to $G D P$ as control variables, as well as year fixed effects. Columns 1 and 2 compare the conditional correlations between Creditor rights and Investment and Asset growth, respectively. Columns 3 and 4 compare the conditional correlations between Creditor rights and risk. The coefficient on Default probability reports the conditional correlation between the dependent variable and Default probability evaluated at the sample mean of Creditor rights. Standard errors (in parentheses under each estimate) are clustered by country. Estimates followed by the symbols ${ }^{* * *},{ }^{* *}$, or ${ }^{*}$ are statistically significant at the $1 \%, 5 \%$, or $10 \%$ levels, respectively. Please refer to Table 1 for a definition of all the variables.

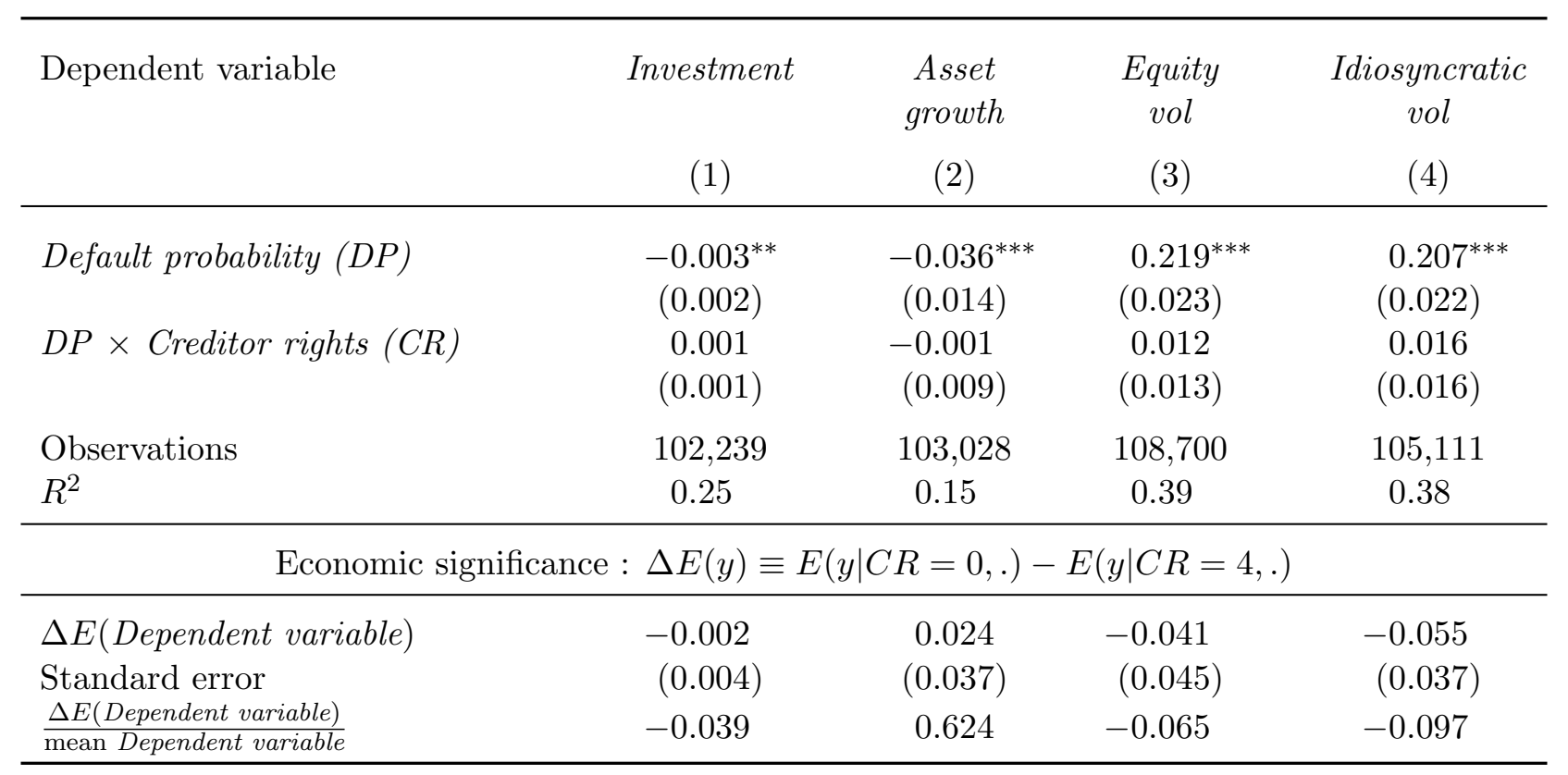




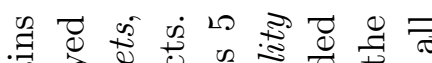
要

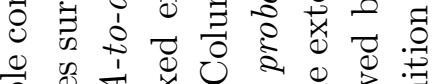

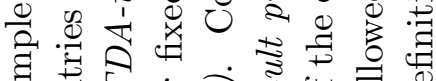

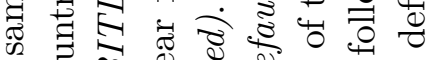

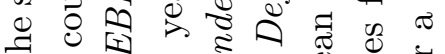
F. 过逑 घิ 击 की

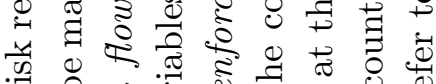

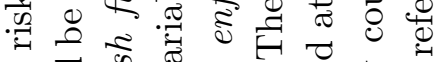
范

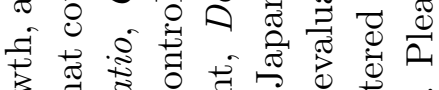

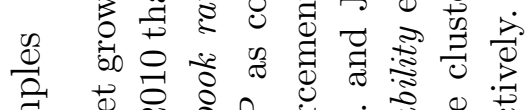

द्वै की

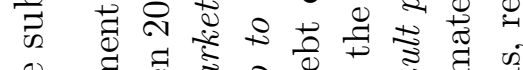

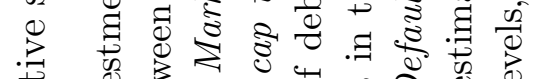

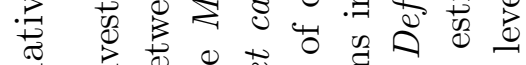

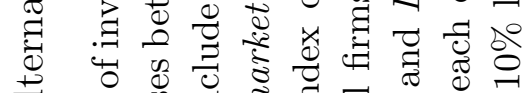

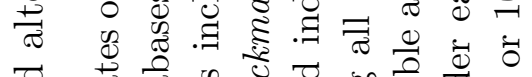

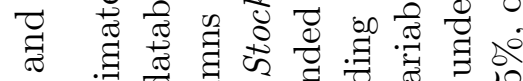

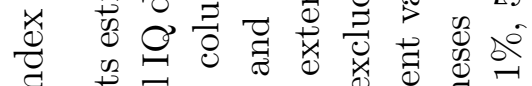

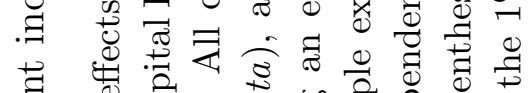

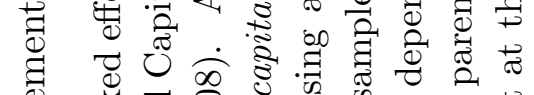

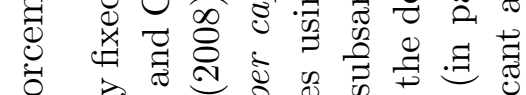
突 5

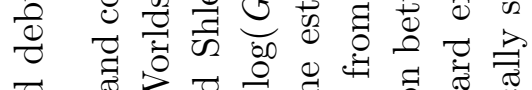
च 言

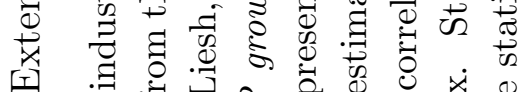

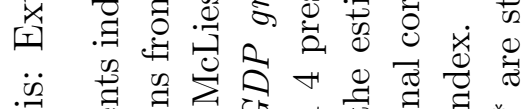

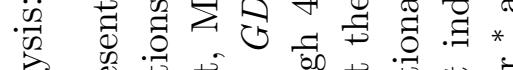

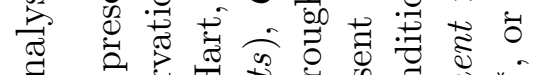

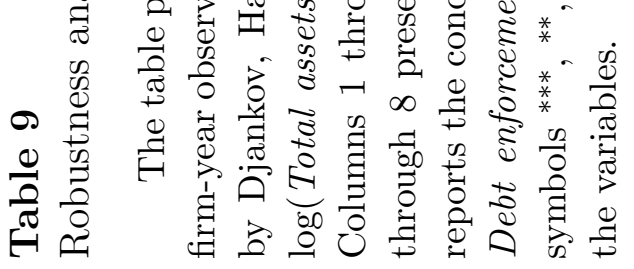

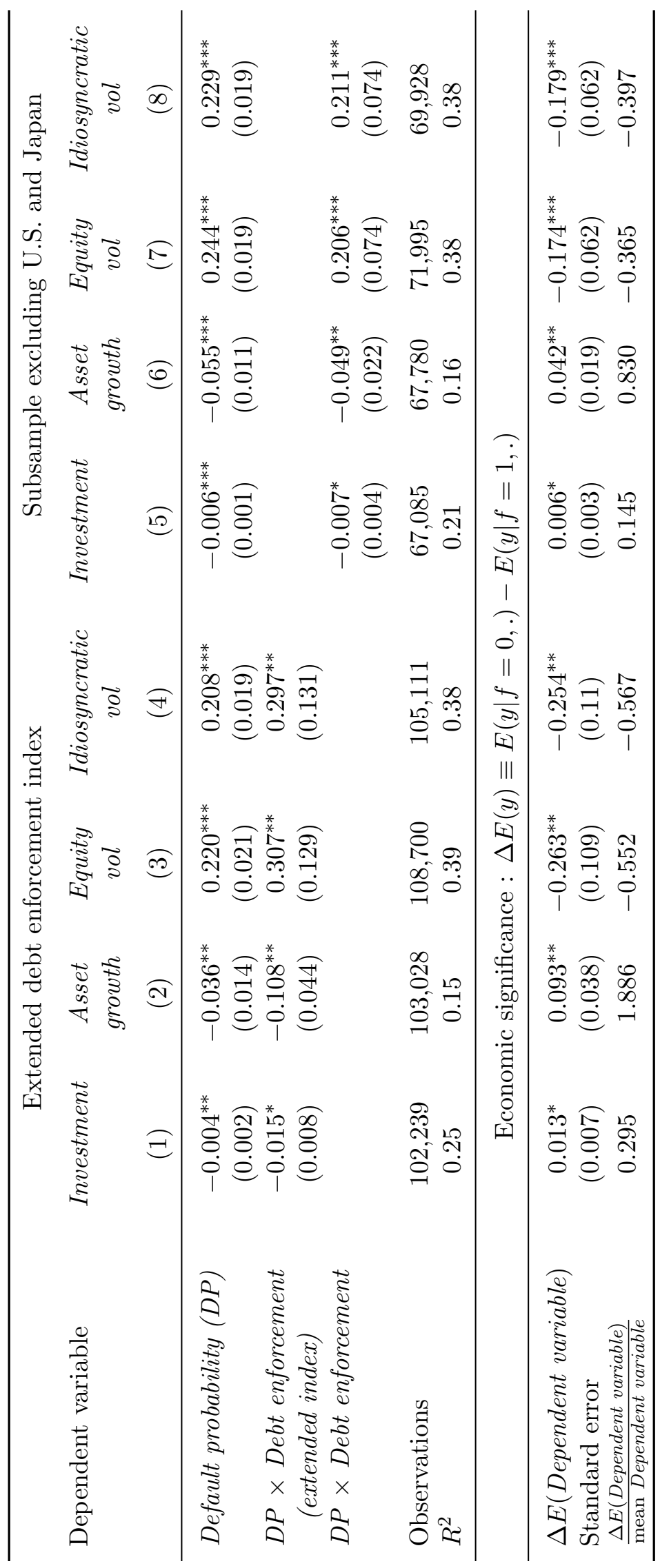

